\title{
POTENTIAL FOR TOURISM IN THE DEMOGRAPHICALLY THREATENED REGION OF JURKLOSTER
}

\section{TURISTIČNI POTENCIAL DEMOGRAFSKO OGROŻENEGA OBMOCJA JURKLOSTER}

Maja Topole

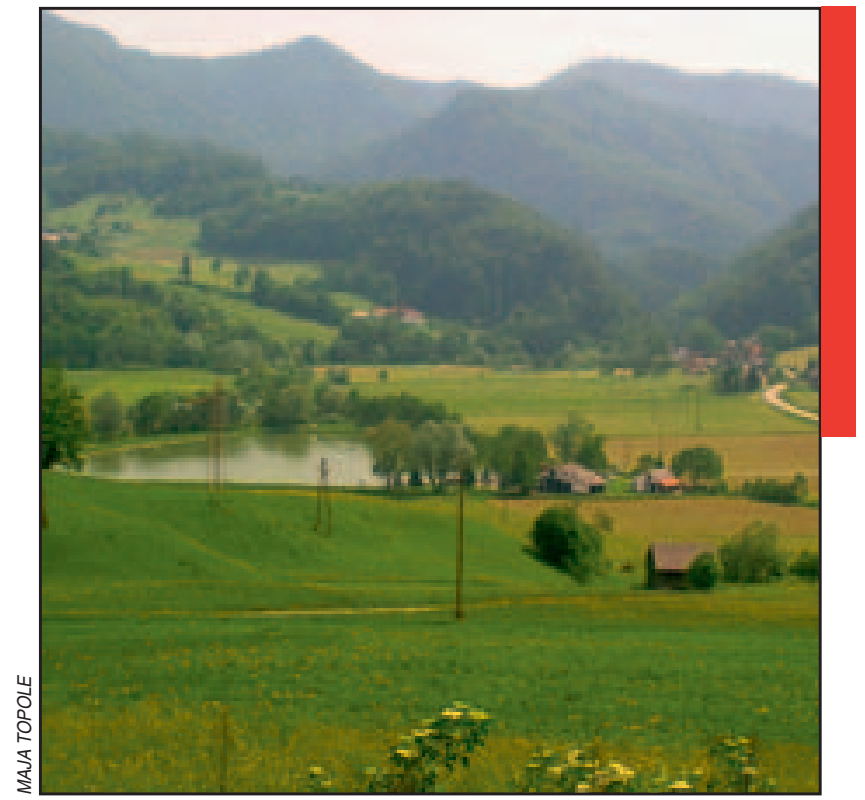

At Mrzlo Polje the Gračnica River leaves an area of less resistant Tertiary rocks and enters the gorge carved into the hard carbonate Triassic rocks of the Litija anticline. Land use and manner of settlement change along with the rock composition.

Pri Mrzlem Polju Gračnica zapušča svet manj odpornih terciarnih kamnin

in vstopa v sotesko, vrezano v triadne trde karbonatne kamnine Litijske antiklinale. S kamninsko sestavo se spremenita tudi raba tal in način poselitve. 


\title{
Potential for tourism in the demographically threatened region of Jurklošter
}

\author{
DOI: $10.3986 / A G S 49104$ \\ UDC: 913:314.116(497.4Jurklošter) \\ COBISS: 1.01
}

\begin{abstract}
This article examines the demographically threatened region of the local community of Jurklošter in the southeastern part of the Alpine Sava Hills (Posavsko hribovje), part of the municipality of Laško. It draws attention to the natural and social conditions in the region after the Second World War, which led to the steady depopulation of the area. The paper presents the characteristics of the geographical location, settlement, settlements, population and land use, and economic development. It emphasizes the significance of the exceptional natural and cultural heritage as bases for strengthening the role of tourism and recreation, which along with some complementary activities could help reverse negative population trends and provide new sources of income. It deals primarily with natural and cultural motives as important components of the tourism potential of the region.
\end{abstract}

KEY WORDS: rural geography, demography, demographically threatened region, natural and cultural heritage, protected area, tourism potential, local community of Jurklošter, Slovenian Sub-alpine region

The article was submitted for publication on April 17, 2008.

ADDRESS:

Maja Topole, Ph. D.

Anton Melik Geographical Institute

Scientific Research Center of the Slovenian Academy of Sciences and Arts

Gosposka ulica 13, SI - 1000 Ljubljana, Slovenia

Email:maja.topole@zrc-sazu.si

\section{Contents}

1 Introduction

2 Population and economic development in the past

Socio-economic conditions today

4 Tourism potential as a basis for new development opportunities for the region

4.1 Geomorphological and hydrographical tourism motives

4.2 Biogeographical tourism motives

4.3 Historical, ethno-social, ambient, paysage and artistic tourism motives $\quad 127$

$\begin{array}{ll}4.4 & \text { Spiritual heritage } \\ 5 & 129\end{array}$

5 Conclusion 130

6 References 131 


\section{Introduction}

The local community of Jurklošter has an area of $42 \mathrm{~km}^{2}$ and is located in the southeastern part of the Alpine Sava Hills (Posavsko hribovje). It lies between the Ljubljana Basin in the west and the Pannonian low Sotla Hills in the east. Its eastern portion reaches to the area of Kozjansko. According to census data from 2002 , only $6 \%$ of the population of the municipality of Laško live in what comprises $21 \%$ of its area. To the south it borders the municipality of Sevnica, to the east the municipalities of Dobje and Šentjur. Before the First World War the number of inhabitants began to decline gradually; after the Second World War depopulation of the area further accelerated. We wanted to identify the reasons for this unfavorable demographic development and determine possibilities for improving the economic situation of the area. We used mathematical-statistical methods and analyzed data from the 2002 population census. In this way we obtained a picture of the age and sex structure of the population there as well as its employment structure, jobs structure, characteristics of natural and migrational changes in the population and a comparison with the wider region. Along with a study of the natural geographic and cultural historical advantages (Topole 2007), we wished to present motives for tourism which could be the basis for the successful development of tourism in the area.

\section{Population and economic development in the past}

Economic development in this area was based primarily on abundant forest and water resources and on limited mineral and energy resources quartz sand, brown coal). Glassmaking developed here (Stara Glažuta, Jurklošter) at the end of the $18^{\text {th }}$ century; after the relocation of the glass factory to Hrastnik in 1860 , the area turned to papermaking and woodworking, and later on the timber industry. Advanced methods of forest management included the cultivation of forest trees and planned reforestation. Trade also flourished, especially with the construction of the Vienna-Trieste railway, since after 1857 this made possible the transport of wood products to distant markets in central Europe, the Balkans, Asia, and northern Africa (Jelovšek 1983). In the $19^{\text {th }}$ century and at the beginning of the $20^{\text {th }}$ century this area reached a peak of development. Whereas

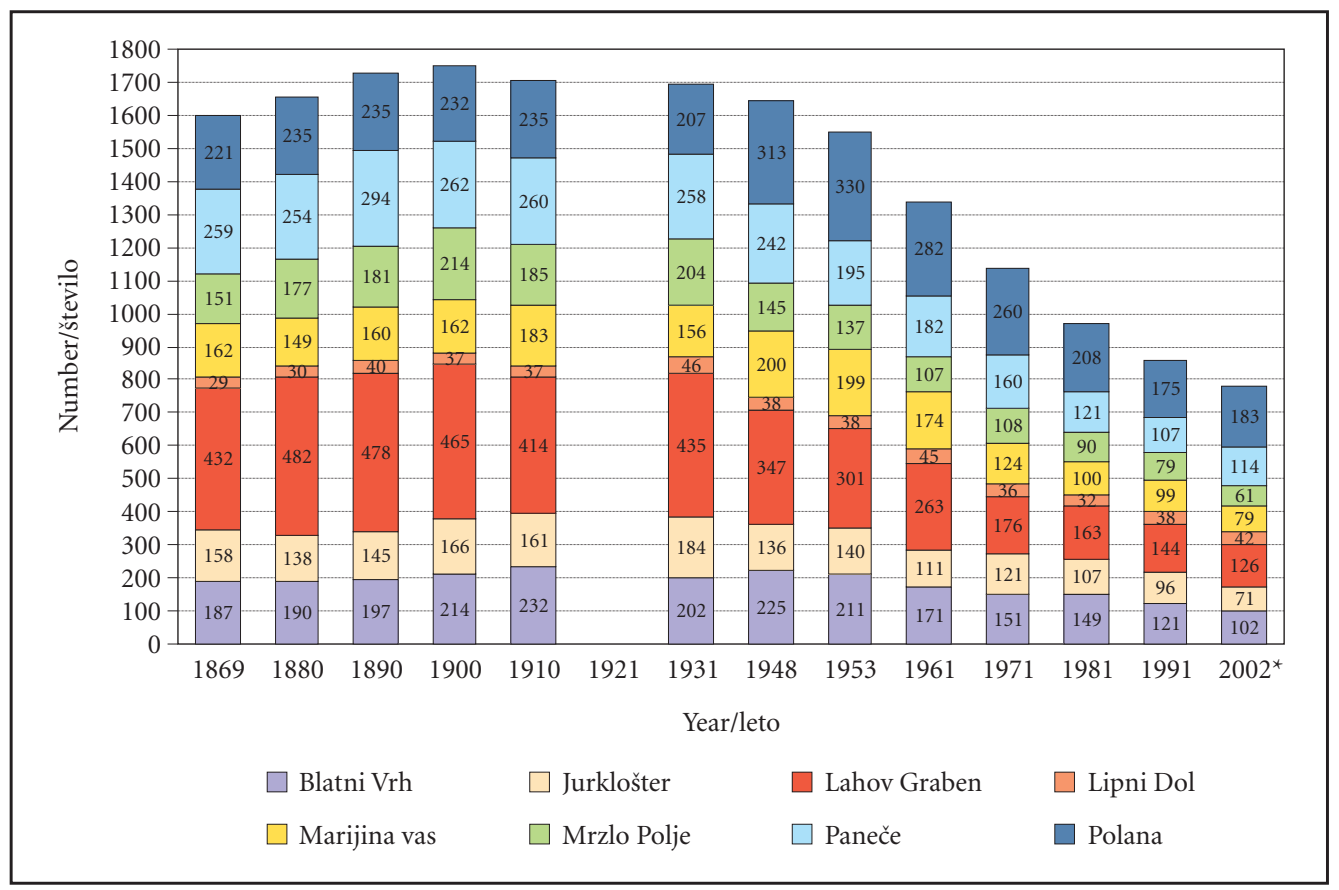

Figure 1: Number of inhabitants according to individual censuses by settlement (Popisi prebivalstva 1869 ...). 
outmigration and population decline was characteristic of most Slovenian rural areas at that time due to a surplus agrarian population, in 1900 the local community of Jurklošter achieved its maximum population: 1752 inhabitants. People had steady work in the factory, forestry, and transport, and at peak times the region even required seasonal workers. Just before the First World War the number of inhabitants began to fall (in 1910 there were 1707), then experienced stagnation up until the Second World War (Popisi prebivalstva $1869 \ldots)$...

The occupation and postwar social processes, nationalization and the relocation of the means of production to other Slovenian towns as well as a worsening of transportation conditions due to destructive mudslides and floods led to the increasing depopulation of the area. Gračnica Creek is a torrential stream and occasionally floods. The worst floods in the area occurred in 1954 (Kolbezen 1993) and brought an end to the operations of the mills and sawmills there. A number of bridges were washed away and mudslides were triggered. Since the road infrastructure was not fully repaired until the 1960s, the area was completely cut off from the west (Jelovšek 1983). Floods, landslips, and slides still threaten the area today at times of heavy precipitation (Dolinar, Vertačnik and Polajnar 2006; Zorn and Komac 2007).

\section{Socio-economic conditions today}

The postwar population (1646 people in 1948) dropped by more than half by the time of the 2002 census (778 people). The population density in the local community of Jurklošter in 1991 was only $21 / \mathrm{km}^{2}$. For comparison, the density in Slovenia as a whole was 97, in the Apine Sava Hills 69, and in the municipality of Laško 72 inhabitants per $\mathrm{km}^{2}$. In 2002 the population density here was only 19 inhabitants $/ \mathrm{km}^{2}$. Thus over a period of 100 years the population was reduced by $55 \%$. The population also has an unfavorable age structure. According to the 2002 census, the share of young people under 15 was $16.6 \%$, and the share of elderly people over 64 was $18.25 \%$. The index of ageing, the ratio between the two numbers multiplied by 100 , has a value between 40 and 50 for populations with normal age structures. In Slovenia in 2002 this value was 96 (Josipovič and Repolusk 2007), and in the local community of Jurklošter it was 110.1. In the period from 1995-2002 there was negative growth in the local community of $-8 \%$. The birth rate during this period was $10 \%$, the death rate was $18 \%$ (for Slovenia as a whole during this same period, the rates were 9.1 and 9.4, respectively). Consequently we can expect a reduced rate of natural increase here. If we take into account the migration patterns of the population, the situation is somewhat improved. In the period from 1995-2002 the growth from immigration was 29 people; in the local community $20 \%$ more people immigrated into the area than moved out of it.

With respect to the working age population, i. e. inhabitants between the ages of 15 and 64, only 280 people, or $55.2 \%$ of the members of this group, were economically active (the figure for Slovenia as a whole is 59.5\%) There have been no significant developments in the region with respect to employment possibilities. $70 \%$ of the working population are commuters. Half of these migrate to other towns within the same municipality, a third to another municipality within the same statistical region, and $17 \%$ have jobs in other statistical regions.

Agriculture and forestry have an above average importance, employing $14 \%$ of the working population. $44 \%$ of the working population are employed in nonagricultural activities and $40 \%$ in services, but these for the most part commute to centers of employment in the Laško municipality or to neighboring Sevnica. 30\% of the working population find jobs in their town of residence. Most of these work in primary activities, in agriculture and forestry; there are only a few nonagricultural and service jobs in the region. Locational divergence, a parameter which shows the discrepancy between the number of economically active people according to place of residence and the number of economically active people according to place of work (number of jobs in a place) has the value of 1 when the two are in equilibrium (Ravbar, 2002). In the local community of Jurklošter this value is 3.11. This means that there are many more workers living in the place than there are jobs for them in that same place. Jobs in primary activities prevent this value from being even greater. The only central settlement is Jurklošter, but this has the role of a central settlement of the lowest level.

The fundamental problems of the area are thus the following:

- susceptibility to natural disasters (floods, slides, landslips, soil erosion);

- a prevailing extensive system of agriculture and forestry which is not tied to other economic activities; 
- a high dependence of the population on commuting to centers of employment outside the region;

- an above average number of economically active people;

- deficiencies and ageing of transportation, energy, municipal and communications infrastructure;

- a relatively weak central settlement;

- insufficient valuing of monuments with natural and cultural heritage value, and

- a lack of clear development plans and protection zones.

\section{Tourism potential as a basis for new development opportunities for the region}

Considering the wealth of natural and cultural points of interest, the region can seek new development prospects in tourism and recreation. Given appropriate promotion, tourist demand can relatively quickly vitalize and stimulate interest among tourist agents. Within the socio-economic elements of the system of tourism as presented by Jeršič 1985 , we are thus primarily interested in what the area could offer to tourists. Its main elements are the following:

- tourism potential (infrastructure, natural and socio-cultural elements of the landscape);

- tourism amenities (accommodation, supply, recreation, entertainment, transportation and information);

- tourism organizations and residents of the receptive tourism regions. In this article we will pay particular attention to tourism potential.

The area under study is located not far from important transportation routes. The main road and the railway Zidani most-Celje with the railway station Rimske Toplice (Globoko) in the Savinja Valley and the main road and railway Zidani Most-Zagreb with the railway station Breg in the Sava Valley are 14 and $12 \mathrm{~km}$ distant respectively. Jurklošter is an interesting destination for day trippers and recreationalists from the nearby spa centers of Rimske Toplice $(19 \mathrm{~km})$ and Laško $(22 \mathrm{~km})$ as well as the urban centers of Sevnica $(20 \mathrm{~km})$, Celje $(33 \mathrm{~km})$ and Krško $(40 \mathrm{~km})$.

Above average natural and socio-cultural elements are a precondition for the tourism and recreational attractiveness of a region. We wish to identify, evaluate, present and prepare them for visits from tourists, which involves ensuring accessibility, required amenities, and protection. Based on a division of monuments into natural and cultural elements, we may distinguish between natural and cultural tourism motives (Jovičić 1980). In the region studied the following are among the most important natural and cultural tourism motives.

\subsection{Geomorphological and hydrographical tourism motives}

A geology and geomorphology guided educational trail could pass through the region, since it is characterized by a great diversity of rocks and a wealth of geomorphological forms, pedological profiles, hydrological phenomena, plant and animal species, and types of land use (Buser 1979; Šifrer 1997; Dozet et al. 1999; Dozet 2003).

The type of relief is dependent on the lithological substrate. Fluvio-denudational valley-ridge sharply dissected relief predominates, while fluviokarst relief (the summit of Lisca) and accumulative relief are rarer (some sections along the Gračnica and the area of Mrzlo Polje). The manner of water drainage is associated with the porosity of the rocks (surface drainage, which predominates, alternates with less common underwater drainage; elsewhere, especially in the wider valley floor, the ground is marshy due to impeded drainage). Due to selective erosion more resistant rocks are often exposed, for example the lithothamnium limestone among the Miocene sands in the area of Marijina vas or the pinnacles and side ridges of the resistant Triassic limestone in the Grohotje gorge. Microclimatic conditions are connected with the relief, as is the manner of arrangement of the forest and of cleared areas.

The view from the north toward the south gives the impression of a heavily forested area, while the view in the opposite direction reveals numerous clearings with small settlements and hamlets. In the area studied rocks of different ages (from Permian and Carboniferous rocks to young alluvial deposits), of different hardness and resistance (from soft ones, such as the highly erodible Oligocene marine clay or marlaceous marine clay in the vicinity of Polana, to the predominant hard limestones and dolomites whose resistance 

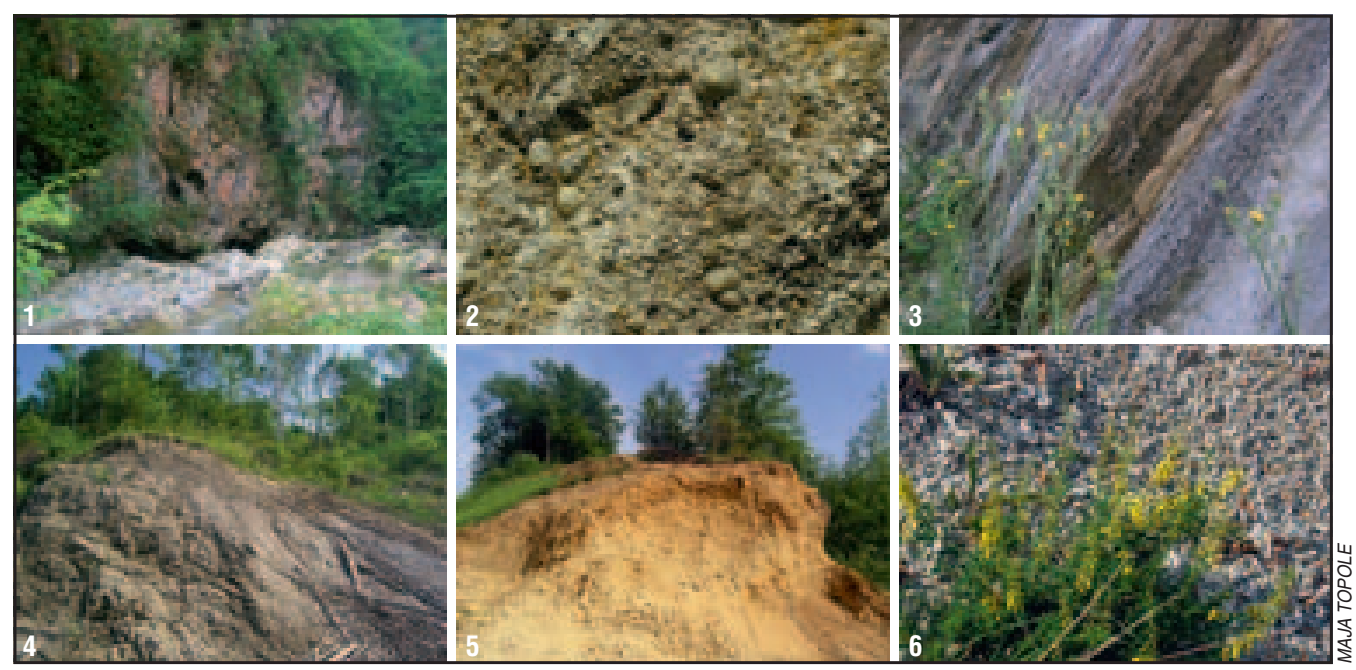

Figure 2: The shaping of the surface, elevation, slope, hydrographical and pedological conditions, land use and settlement are strongly dependent on the lithological substrate. In the area of the local community of Jurklošter we find among others: 1. carbonate rocks (limestone and dolomite), which predominate and are most resistant and associated with the greatest inclinations of slopes, 2. quartz conglomerates and sandstones, 3. Carboniferous shales, visible in the exposed core of the anticlinal, 4. Oligocene marine clay in the area of Polana, which is strongly susceptible to erosion, 5. and 6. weakly resistant Tertiary (Oligocene and Miocene) sands, which are preserved on the surface only in sheltered locations.

is increased by nodules of flint), from very fine (Oligocene and Miocene sands, recent gravels) to compact, from water permeable carbonates to impermeable silicates, from sedimentary to rare volcanic, which arose from volcanism in the Tertiary there (Blatni Vrh). The landscape has a mixture of more rounded and sharper peaks, of rounded slopes and sharp ridges, of side ridges, gorges, narrow, steep V-shaped valleys and wider valley sections with flood plains and even marshy bottoms, sharp trenches and ravines and dells, steep precipitous slopes and flattened karstified land, gentle slopes and rocky cliffs, pinnacles and rock shelters (Topole 2007). Among the interesting surface forms can be included two natural monuments two horses carved into the gorge of the Gračnica not far from Rimske Toplice, which served as a signpost in the Middle Ages (Gržan 2006).

Especially attractive are the areas of higher elevation - in the central forested part (Fesinge, $643 \mathrm{~m}$; Artvišče, 644 m; Tajna - Sv. Trojica, $851 \mathrm{~m}$; Voluš, $778 \mathrm{~m}$ ), in the southern and highest part the ridge with numerous peaks offering panoramic views (Radež, 765 m; Vršica, 771 m; Lisca, 948 m; Mala Lisca, 934 m; Ješovec, $934 \mathrm{~m}$; Ivc, $875 \mathrm{~m}$; Ojstrež, $917 \mathrm{~m}$; Rudenik, $900 \mathrm{~m}$ ). The ridge is part of a nappe front which goes from Podkum past Radeče along the southern side of Lisca all the way to Bohor in the south (Buser 1979). Because the geological strata were pushed towards the south, the northern slopes are at a 20 to $30^{\circ}$ incline, while the southern slopes above the Sava often exceed $30^{\circ}$ and in many places have the form of a 100-meter or even higher precipice. From the standpoints of relief, climate (Gams 1972), and vegetation, a ridge means a transitional zone where elements of the sub-alpine and Dinaric environments come into contact. The pronounced relief boundary with which the flow of the Sava River is associated also functioned as a provincial boundary in the past. This was where the border between Styria and Carniola was located.

The local community of Jurklošter has a dense river network despite the predominance of carbonate rocks due to often impermeable flint nodules and the steep slopes. It belongs mostly to the Gračnica river basin ( $96.6 \mathrm{~km}^{2}$; Kolbezen 1998) with the exception of the southwestern slope of Lisca, which drains directly into the Sava (the creeks Podvinski, Liški and Črni potok). The Gračnica is a $25 \mathrm{~km}$ long watercourse which rises at an elevation of $550 \mathrm{~m}$ north of Planina pri Sevnici, flows towards the west and discharges into the Savinja southeast of Rimske Toplice. From source to mouth there is a height difference of $350 \mathrm{~m}$. It has the character of a mountain or torrential stream with an alpine rain-snow water regime, for which the primary peak is characteristically in April, and a secondary one in November or December (Hrvatin 1998). Due to lithological and relief differences the creek has varying erosional capabilities. It has 


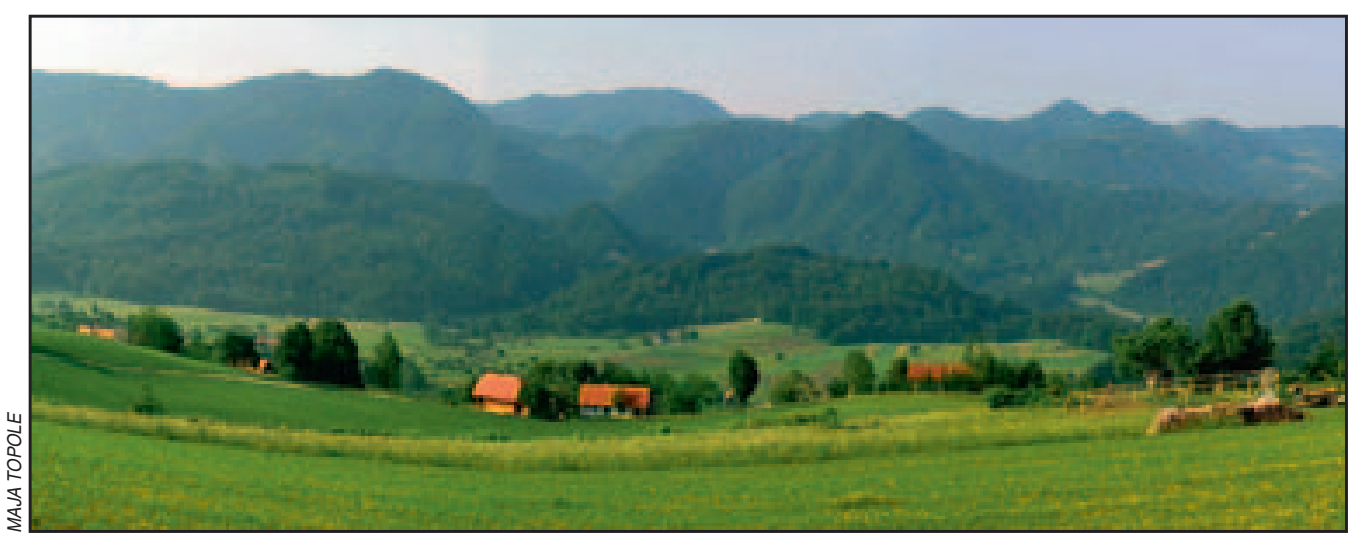

Figure 3: View from Vrh nad Laškim $(565 \mathrm{~m})$ towards the south of the dissected forested area of the local community of Jurklošter. Forest takes up almost three fourths of the total area. In the background is Lisca $(948 \mathrm{~m})$.

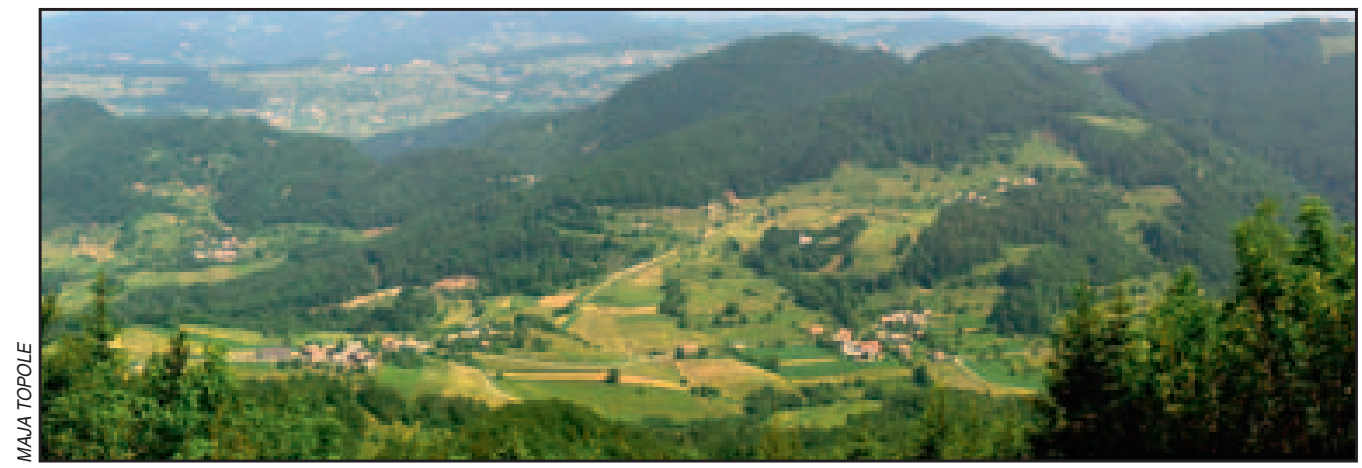

Figure 4: View from Lisca $(948 \mathrm{~m})$ to the north. The difference between the higher and steeper ground on the resistant Mesozoic carbonate rocks and the lower surfaces of milder forms on the less resistant Tertiary rocks is evident. The first is covered with dense forest (Lapor, Sekovca, Tajna) while the second is cleared and settled (in the foreground Paneče and Polana, in the background Vrh nad Laškim).

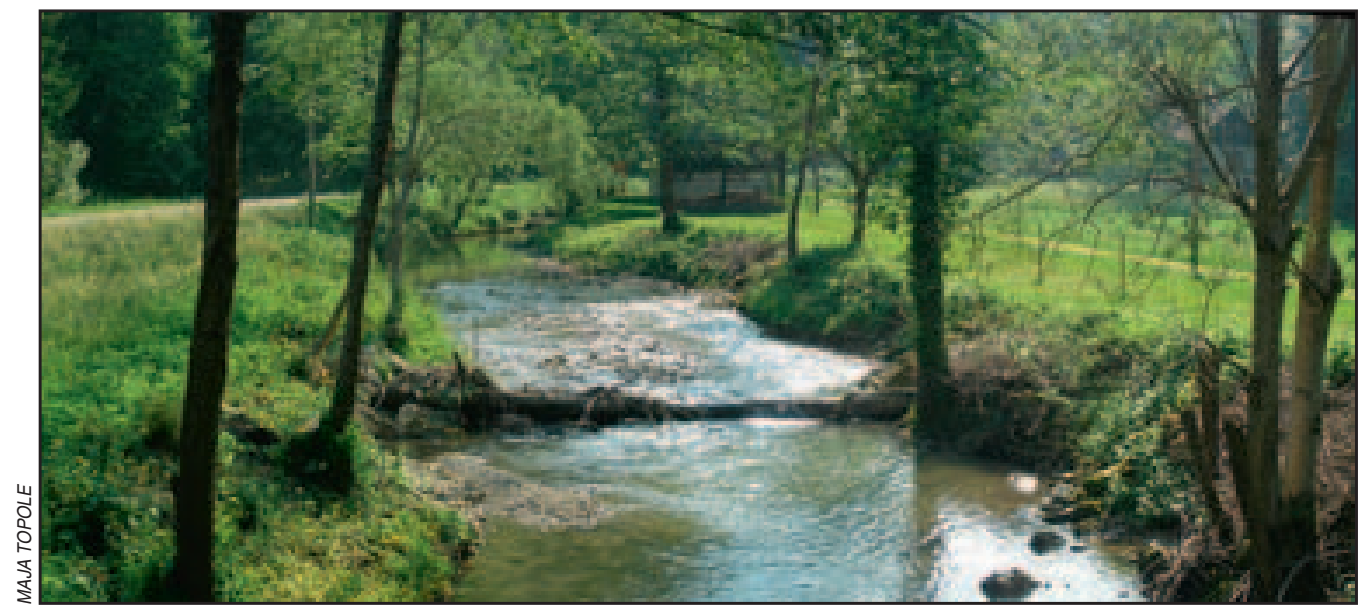

Figure 5: The Gračnica, a creek with characteristics of a mountain torrential stream, can rise quickly in times of heavy precipitation, especially in summer. 


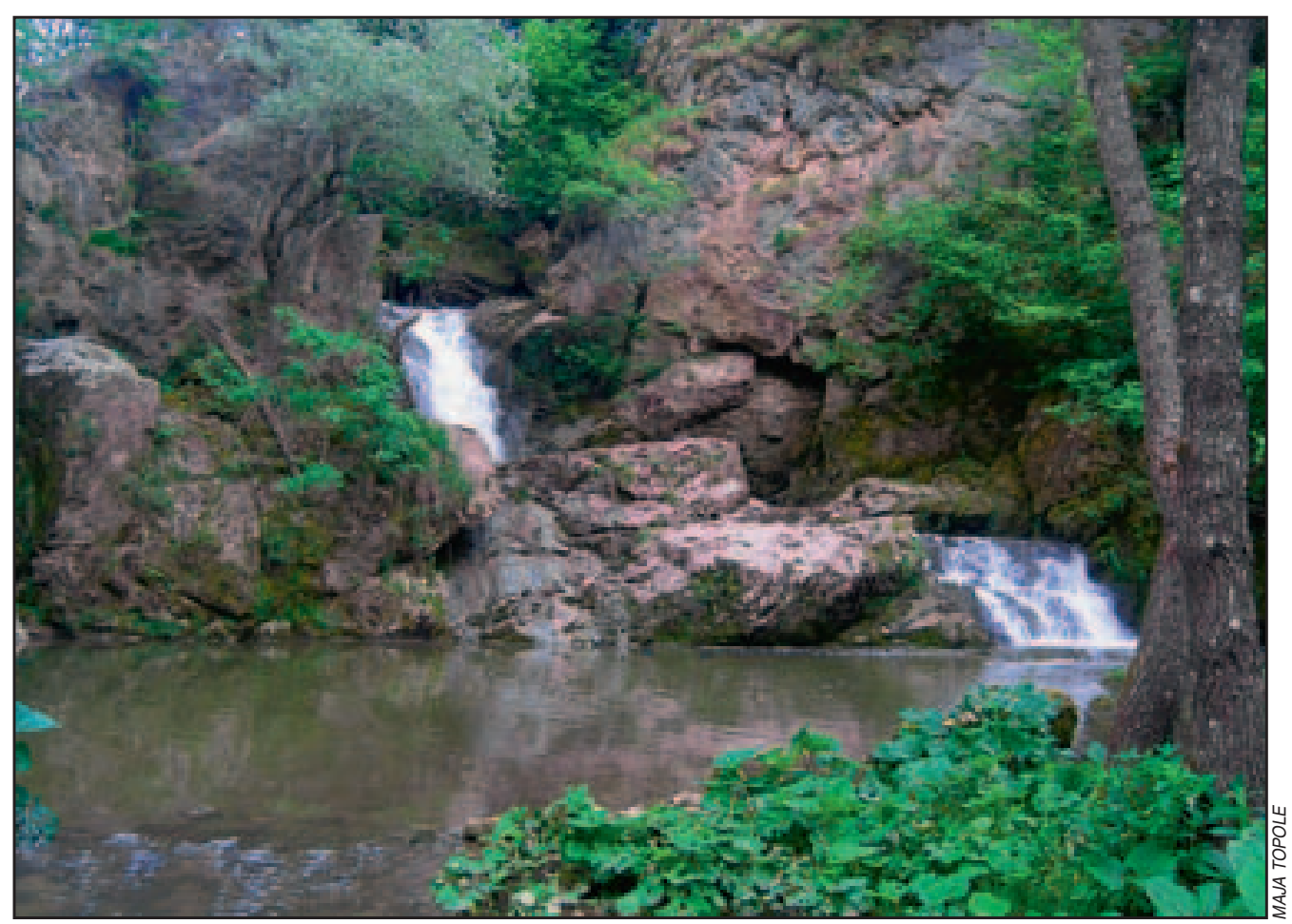

Figure 6: Gračnica Waterfall (Gračniški slap) near Marof in Mrzlo Polje. The water flows along a soft Miocene marlaceous substrate and drops in two 8 and 4 meter falls over tectonically uplifted dolomite barriers. It continues its course towards Jurklošter through a narrow gorge.

a complicated course already before Mrzlo Polje. A peaceful flow along a marlaceous bed, which is partially regulated (Govedič et al. 2006), is interrupted by barriers made of a limestone-quartz conglomerate. The creek overcomes these in varying ways: by flowing around them, by carving gorges, and by forming small waterfalls. Počerenje Waterfall (Počerenski slap) is particularly picturesque (Ramovš 1997).

Along the soft Micoene marlaceous substrate which follows, there are a number of fish ponds which arose from the damming of the Gračnica near Marof. They play an important role in fish-farming, fisheries, and recreation.

Gračnica Waterfall near Marof (Mrzlo Polje) marks the border between Tertiary and Triassic geological substrates, or between the soft Miocene layers in the east and the hard dolomite in the west. Here the character of the valley completely changes, as does the land use: to the east is a largely cleared and settled landscape with gentle landforms while to the west is higher and more dissected land dominated by forest. Between the two transverse joints is a tectonically uplifted dolomite wall into which the Gračnica could not carve fast enough, thus a small lake arose here. Part of the water was used by local inhabitants to power a saw, part of it falls over the wall in two waterfalls which are 8 and 4 meters respectively. Below the two walls there are pools. The area is considerably broken up and cut apart tectonically into stone blocks (Ramovš 1983).

The course of the Gračnica between Mišji Dol and its discharge into the Savinja is especially scenic. Here we have a case of inverse relief, since the creek is carved up to $500 \mathrm{~m}$ deep in the northern wing of the Litija anticline. The Grohotje gorge was formed at the same time by folding and there arose a large incised meander. Due to lithological differences and tectonic influence, canyon and wider valley sections alternate, and there are also pinnacles, cairns, rock obstacles and extremely steep trenches. The valley floor is settled only in the wider portion (Lipni Dol). Elsewhere there are only individual water-powered mills, while homes are scattered higher up along the sunny slopes above the right bank of the Gračnica.

The landscape is part of the Inner Dinarides and it is of interest also from the standpoint of tectonics. Paleozoic, Mesozoic, and Tertiary rock layers underwent folding due to pressures from the north in 


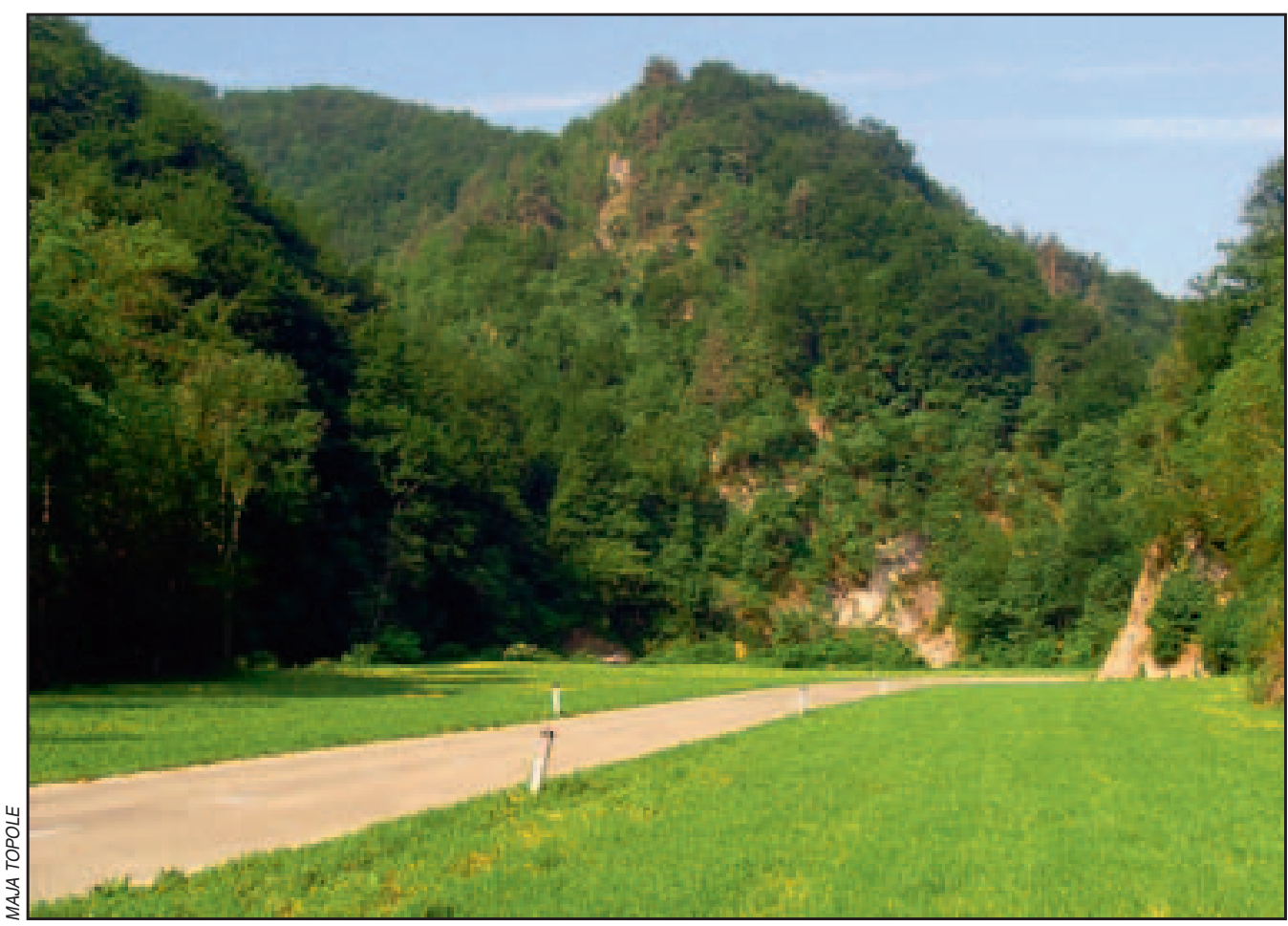

Figure 7: The Grohotje gorge at Lipni Dol. A series of expanded areas with narrow flood plains and narrow areas between the mighty rock side ridges and pinnacles are ranged along the $500 \mathrm{~m}$ deep valley carved into the hard carbonate rock.

the Tertiary and Quaternary, then later the region was also tectonically fractured (Placer 1999). At tectonic faults and their contact zones there are sources of thermal water $\left(21-43^{\circ} \mathrm{C}\right)$ not far from Jurklošter (Rimske Toplice, Laško). The area belongs to the Planina-Laško-Zagorje geothermal region (Slovenski E-forum 2008).

\subsection{Biogeographical tourism motives}

The local community of Jurklošter is a heavily forested landscape dominated by various beech associations (Marinček and Carni 2002). Due to the large share of resistant carbonate rocks and steep land influenced by thermal inversion, forest covers $73 \%$ of the total area. The region belongs to the sub-alpine phytogeographical zone but its transitional nature must be stressed. Not far away to the southeast is the contact area of the sub-alpine, sub-pannonian and sub-dinaric phytogeographical zones, which is associated with tremendous diversity of flora. There are even glacial relicts to be found on the carbonate substrate of some summits and steep shaded slopes, while thermophilic plant species grow in sunny habitats (Wraber 1960).

The forest offers shelter to a number of different animal species, in particular red deer, roe deer, and wild boar. Precious habitat is also offered by the waters of the area, which are home to a variety of threatened fish species (Govedič, Kotarac and Grobelnik 2006).

\subsection{Historical, ethno-social, ambient, paysage and artistic tourism motives}

This is a very old cultural landscape with important cultural and historical landmarks.

Archeological finds show that the area of Jurklošter was settled as early as in the Paleolithic. Major transportation routes along the Savinja, the Sava, and through the pass of Sele, $675 \mathrm{~m}$, below Lisca, attracted 


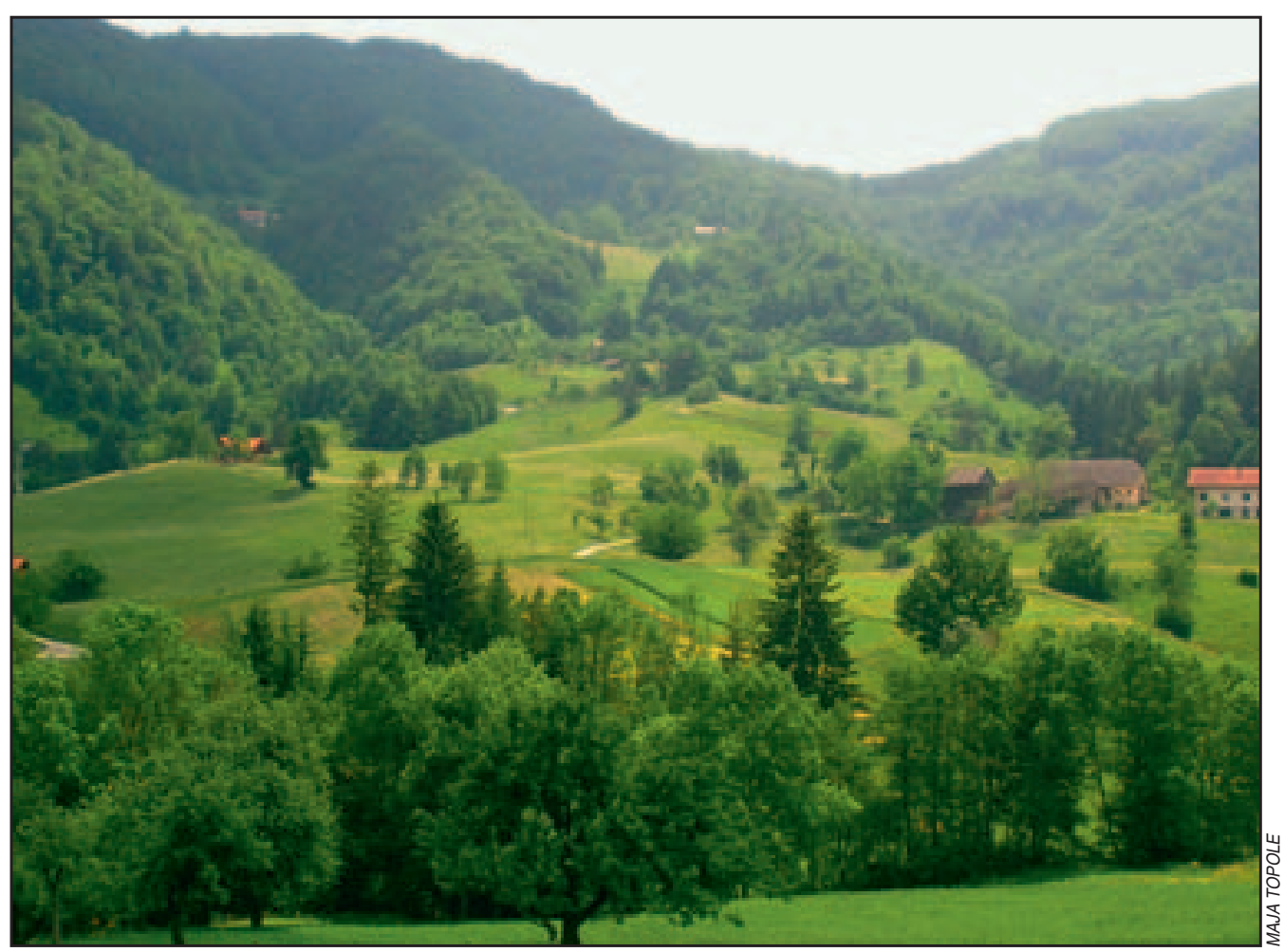

Figure 8: The majority of the settlements here consist of small hamlets and isolated farms which extend well above the valley floor. Pictured is the shaded side of Lisca with the hamlet of Stara Glažuta (500 m) in Lahov Graben.

people throughout all periods, but density of settlement was low even in Roman times. Characteristic of Roman times was the siting of settlements lower down, in the immediate vicinity of traffic routes and fertile fields, and this kind of land in the area under study was scarce. In Late Antiquity, the period from the second half of the $4^{\text {th }}$ to the end of the $6^{\text {th }}$ century, the role of less accessible places increased with the Barbarian invasions, since such places offered greater protection. Inhabitants took to more remote, higher, and less accessible parts of hilly areas. Here military garrisons also built forts. In the local community of Jurklošter are the well-known remains of the fortified settlements Gradec near Prapretno and Vranja Peč near Lipni Dol. The first even belongs among the most important Late Antiquity monuments from the Eastern Alps region (Ciglenečki 1992; Ciglenečki 2007).

Later on monks had a significant influence on settlement. In the $12^{\text {th }}$ century the Carthusians settled here, followed by the Jesuits in the $16^{\text {th }}$ century. The monastery was abolished with the Josephine reforms of 1773 (Orožen 1976).

At the intersection of the alpine (sub-alpine), sub-pannonian and dinaric regions, areas of lower Tertiary land, where the forest for the most part has been cleared, and rolling forested areas on hard carbonate rock substrate alternate. Forest covers almost three-fourths of the total area and has for the most part a protective function. It grows on very steep land and resistant carbonate rocks, and the average slope is $26^{\circ}$. In contrast the average slope of the cleared area is only $14^{\circ}$; most frequently it is used for meadows and pasture (Karta dejanske rabe tal 1996 and 2001/Map of actual land use 1996 and 2001). Although the settled area takes up only 2.6 percent of the total area (Topole 2007), the built heritage contributes greatly to the attractiveness of the landscape. Houses here are classified as the Central Slovenian type, which is closer to the alpine type of house than the Pannonian type (Drozg 1998). Characteristic of settlement on the valley floor is a roadside settlement pattern (along watercourses only water-powered plants - sawmills, mills, small hydroelectric power stations), while for slopes, ridges, summits, and passes, settlement is typ- 
ically dispersed in the form of isolated farms. Of special mention are individual historical, artistic and technical buildings such as the so-called Vila Haus, an old administrative building for the glass factory, later passing to the ownership of the manor, the Carthusian complex in Jurklošter with the remains of the monastery and surrounding walls, with the late Romanesque or Early Gothic Church of St. Mauritius and with the castle building dating from the end of the $18^{\text {th }}$ century, and the bridges over the Gračnica.

\subsection{Spiritual heritage}

The rich spiritual heritage is connected mainly with the former famous religious and cultural center, the Carthusian monastery in Jurklošter. It was founded around 1170 and is one of the oldest of its kind in Central Europe. Here some important historical personalities worked in peace and solitude, among them medieval writers: Odon of Novara (prior from 1189-1190), the poet Sifrid of Swabia (mid-13 ${ }^{\text {th }}$ century), Michael of Prague (prior from 1391-1401) and the author of religious, linguistic, philosophical and pedagogical essays, as well as the author of the first printed book in Slovenia Nikolaj Kempf (prior from 1449-1451 and again from 1467-1490) (Mlinarič 1991; Gržan 2006).

There is an herb garden in the monastery complex. It has all of the elements of a medieval monastic garden and was once an important source of herbs for healing.

Scholars also connect a tragic story about Frederick II of Celje and his second wife Veronika Deseniška in the $15^{\text {th }}$ century with the monastery. It is believed that she was buried in the chapter of this monastery, but her grave was desecrated in 1471 during the Turkish invasion (Gržan 2006).

Since the Gračnica is included in the network of specially protected areas Natura 2000, with the intent of maintaining or renewing the favorable state of preservation of natural habitats and free-living animal

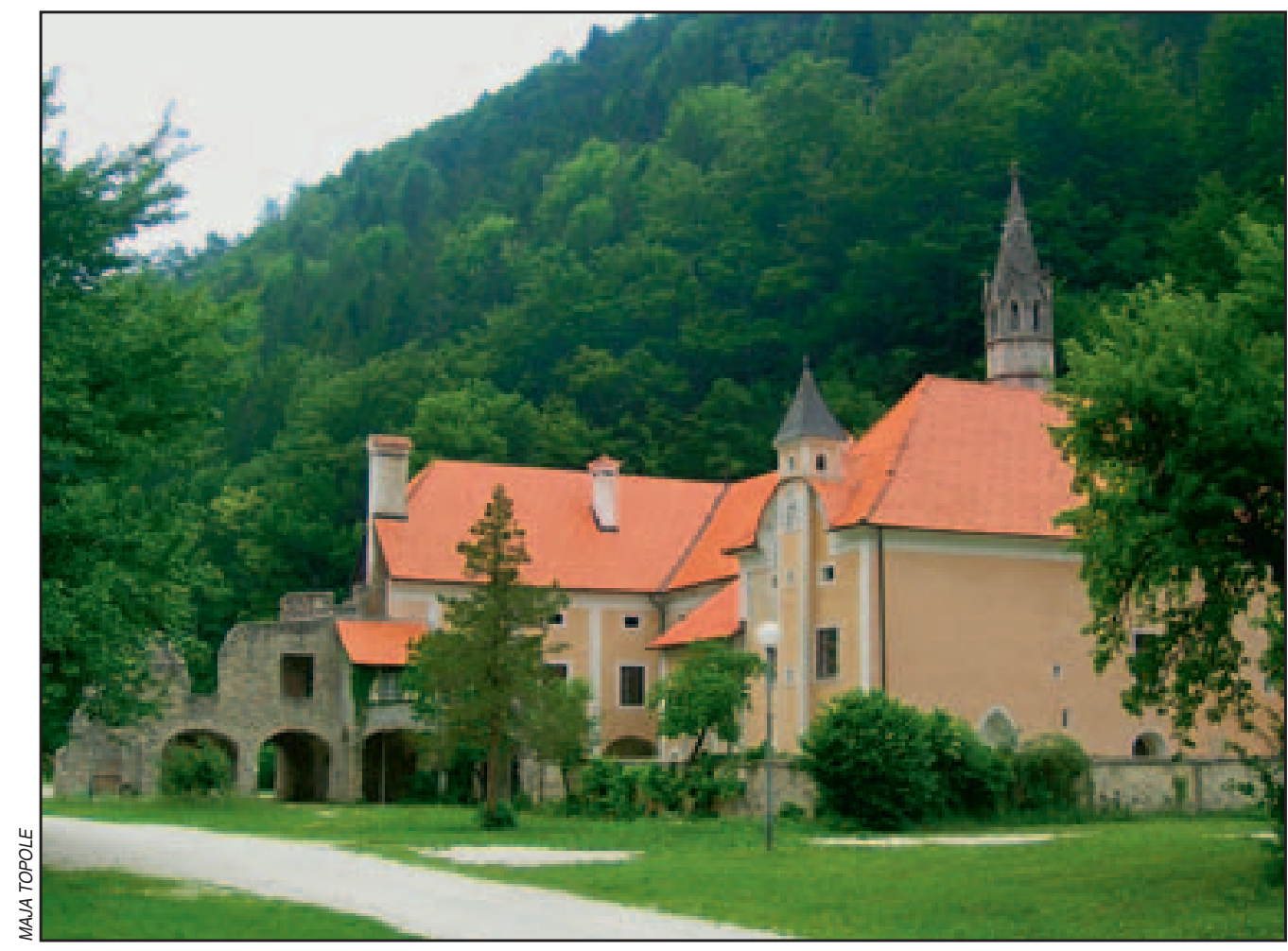

Figure 9: The Carthusian monastery has had a many-sided and important role in the history of Jurklošter. In the Middle Ages it was home to a number of writers of European importance. Recently it has once again become an important religious, spiritual and cultural center which is also of interest to tourists. 
and plant species (Uredba ... 2007), we also identify sustainable tourism or ecotourism and cultural tourism as one of the various possibilities for tourism development in this area.

Natural conditions make possible a wide variety of forms of recreation (cycling, running, hiking and walking, roller-blading, hunting, fishing, rowing, kayaking and canoeing, climbing, archery, horseback riding, cross-country skiing and downhill skiing), but the planning of such activities must be undertaken very carefully. One proposed possible measure for sustainable tourism development policy can be found in the document "Norms for the implementation of spatial plans for tourism « (Jeršič 1998).

Negative impacts from recreation can be avoided by designating zones of protected areas: strictly protected areas, areas in which environmentally friendly forms of tourism may be developed, and areas where the development of tourism infrastructure is allowed (Osnovne smernice ... 2003). They can be minimized by encouraging visitors to stay on trails, by ensuring the technical quality of trails and by providing sufficient information about monuments (Golob and Polanšek 2009). The impact of recreation also depends on the status of a recreational area. Legalizing the status of specified recreational areas enables better monitoring than in the case where there is a predominance of areas which are intended only partially or occasionally for recreation.

\section{Conclusion}

The local community of Jurklošter comprises the western part of Kozjansko, part of the lower Posavje region and the southeastern part of the relatively impassable Alpine Sava Hills (Posavsko hribovje). It has great natural and cultural potential which the local community once fully utilized. It achieved a maximum population size at the turn of the $20^{\text {th }}$ century, had a highly developed economy, including nonagricultural activities, and even required additional labor force. It had a positive migration balance since workers from elsewhere migrated into the region. After the Second World War sociopolitical and economic conditions in the region became extremely unfavorable. Existing means of production were taken from the region and moved to other Slovenian towns. Circumstances worsened even more drastically with the catastrophic storm in June of 1954, which caused the destruction of several bridges and water-powered plants and also triggered a number of mudslides. The road along the Gračnica, which connected Jurklošter with the main road along the Savinja $12 \mathrm{~km}$ distant, was not repaired until the 1960s. Local residents, who even before then had seen the loss of most of their jobs, could not commute to major centers of employment and supply-Rimske Toplice, Laško and Celje. In the first decade the region lost 17\% of its population, and according to the most recent census (2002) it had only half as many inhabitants as a century earlier.

Given that the predominant use of land in the region is for forest (73\%), farming with forestry, which employs $14 \%$ of the economically active population, will continue to have a relatively important role. But it needs to be intensified, rationalized, and modernized. The heavy dependence of the population on daily commuting to centers of employment up to $30 \mathrm{~km}$ distant from Jurklošter could be lessened through appropriate measures with the planned development of tourism and related activities. This kind of development is already enabled by the wealth of diverse tourism motives which we have presented (geomorphological, hydrographical, biogeographical, historical, ethno-social, spiritual, ambient, paysage and artistic tourism motives), but it would be necessary for the local population to become equipped, organized, and qualified in the field of tourism:

- construction of a modern heating center using wood biomass (good practice is already known in Slovenia, for example KIV Vransko d.d. 2008). The effect can be many-sided - socio-economic, ecological and political: obtaining woodchips, utilization of renewable sources of energy, cleaning up the forest and making use of the abundance of wood from trees downed in storms, reduction of costs for heating buildings and water, reduction of emissions, reduced dependence on foreign energy sources and the creation of new jobs.

- the introduction of farm stores and along with this the more successful marketing of agricultural products locally made and produced, especially in the case of ecological farming and the development of tourism;

- the introduction of crafts which complement tourism and recreation (for example, the revival of what used to be important woodworking shops and a continuation of the tradition of herbalism);

- the development of personal services; 
- the creation of a literary park and the development of cultural tourism following the model of some examples from other countries (Literarni park 1; 2; 3 ... 2008). A stimulating environment, the history of the region and the stories associated with it could influence the inspiration of artists' words;

- improvement of the main road through the Gračnica valley (on the one hand ensuring better driving conditions for motor vehicles, while on the other limiting traffic congestion through the introduction of an access fee);

- creation of a network of cycling paths;

- creating a central footpath;

- establishment of transportation and information centers at the entrance to the Gračnica and the railway stations Rimske Toplice (Globoko) and Breg (making available promotional and informational material about natural and cultural points of interest, restaurants and places of interest to visitors, with information about capacity and opening times, supply of itineraries, proposals for thematic routes, organization of transportation for visitors who travel to points of departure using public transport such as buses and trains (taxi service, carriages, bicycle hire, tourist bus or minivan, organization of trips);

- ensuring sustainable mobility and introducing incentives for railway users;

- establishing zones of protected areas (three zones of protective regimes of differing degrees of strictness);

- establishment of central cultural-informational points in Jurklošter (a museum, auditorium, educational center, cultural center);

- creation of a website for the local community of Jurklošter;

- creation of an electronic network of services (for arranging in advance transportation, visits to cultural landmarks, organization of excursions and guided walks and cultural events)

- preparation of itineraries and thematic (educational) trails and maps;

- placement of information panels, signposts, rest areas (parking areas), viewpoints, and picnic areas along various routes;

- arrangement of solid waste disposal;

- arrangement of a water supply network, sewage system and wastewater plants;

- connection and cooperation of the public and the private sectors (for example, the spas in Laško and Rimske Toplice and providers of tourism services in the local community of Jurklošter);

- education and training of local residents for the provision of services associated with tourism;

- construction of catering and overnight capacities and small-scale sports facilities.

We have thus provided a basis for identifying the unique qualities of the local community and the meaning of the identity of the area. The next step to be taken is the active protection of the advantages identified, their strengthening and their promotion. We can invite new visitors to the region and contribute to their education and cultural realization. We can even create a trademark. But tourism and recreation in the region must be planned in accordance with the principles of sustainable development, which means that the qualitative and quantitative capacities of the agrarian landscape must be respected - not only from a technical and economic standpoint but also from an ecological and psychological one. Only in this way will this small rural region become known and be able to preserve its attractiveness and competitiveness.

\section{References}

Buser, S. 1979: Osnovna geološka karta SFRJ 1: 100.000, Tolmač lista Celje L 33-67. Beograd.

Ciglenečki, S. 1992: Pólis Norikón, Poznoantične višinske utrdbe med Celjem in Brežicami. Podsreda.

Ciglenečki, S. 2007: Območje Jurkloštra od prazgodovine do ustanovitve samostana. Ljubljana.

Dolinar, M., Vertačnik, G. 2005: Obilne padavine med 20. in 22. avgustom 2005. Ujma 20. Ljubljana.

Dozet S., Rijavec, J., Grad K. 1999: Western Kozje area Tertiary (Eastern Slovenia). RMZ - Materials and geoenvironment 46-3. Ljubljana.

Dozet, S. 2003: Geološka zgradba Kozjanskega med Savinjo in Rudnico; Prvi del: mlajši paleozoik in mezozoik. RMZ - Materials and Geoenvironment 50-3. Ljubljana.

Drozg V., 1998: Kmečka hiša. Geografski atlas Slovenije. Ljubljana.

Državna topografska karta 1:25.000. Sevnica 122. Geodetska uprava Republike Slovenije. Ljubljana, 1998.

Državna topografska karta 1:25.000. Senovo 123. Geodetska uprava Republike Slovenije. Ljubljana, 1998. 
Gams, I. 1972: Prispevek h klimatografski delitvi Slovenije. Geografski obzornik 19-1. Ljubljana.

Golob, A., Polanšek, B. 2009: Načrtovanje turizma in rekreacije v gozdnatih območjih Natura 2000. Gozdarski vestnik 67-3. Ljubljana.

Govedič, M., Kotarac, M., Grobelnik, V. 2006: Popis kvalifikacijskih vrst rib (Pisces), ukrajinskega potočnega piškurja (Eudontomyzon mariae) in koščaka (Austropotamobius torrentium) s predlogom conacije Natura 2000 območja Gračnica. Phare čezmejno sodelovanje Slovenija-Avstrija 2003. Miklavž na Dravskem polju.

Gržan, K. 2006: Skrivnosti starodavne kartuzije. Ljubljana.

Hrvatin, M. 1998: Pretočni režimi v Sloveniji. Geografski zbornik 38. Ljubljana.

Jelovšek, E. 1983: Jurklošter nekoč in danes. Maribor.

Jeršič, M. 1985: Turistična geografija. Ljubljana.

Jeršič Matjaž 1997: Predlog prostorske zasnove turizma. Določitev izhodišč in opredelitev kriterijev za oblikovanje prostorske zasnove območij, objektov in naprav v prostorskih dokumentih. Ljubljana.

Jeršič Matjaž 1998: Norme za izvajanje prostorske zasnove turizma. Določitev izhodišč in opredelitev kriterijev za oblikovanje prostorske zasnove območij, objektov in naprav v prostorskih dokumentih. Ljubljana.

Jeršič Matjaž 1998: Zasnova rekreacije v prostoru. Ljubljana.

Josipovič, D., Repolusk, P. 2002: Starostna in spolna sestava ter rodnost prebivalstva. Popisni atlas Slovenije. Ljubljana.

Jovičić, Ž. 1980: Osnovi turizmologije. Beograd.

Orožen, J. Jurklošter

Jurklošter (samostan/dvorec)/Gairach. Internet: http://www.gradovi.net/show.php?id=11 (15.7.2008).

Karta dejanske rabe tal (podlaga: letalski posnetki, povečani na merilo 1:5000 (digitalni ortofoto) iz obdobja med letoma 1996 in 2001). Ministrstvo za kmetijstvo, gozdarstvo in prehrano Republike Slovenije. Ljubljana.

KIV Vransko d. d., Tehnološki center. Internet: http://www.kiv.si/slo/ (10.9.2008).

avtor, Klimatografija Slovenije: Količina padavin, obdobje 1961-1990. Ljubljana, 1995.

avtor, Klimatografija Slovenije: Temperatura zraka, obdobje 1961-1990. Ljubljana, 1995.

Kolbezen, M. 1993: Velike poplave in povodnji na Slovenskem - III, povodenj v porečju Savinje junija 1954. Ujma 7. Ljubljana.

Kolbezen, M. 1998: Površinski vodotoki in vodna bilanca Slovenije. Ljubljana. /obstaja že novejša, delo Petra Frantarja, izšla lani

Literarni park 1. Internet: www.parchiletterari.com (18.8.2008).

Literarni park 2 (ali kakršnokoli ime že ima). Internet: http://www.parcoletterario.it/index.htm (18. 8. 2008).

Literarni park 3. Internet: http://www.associazionelafinestra.it/parchi/Introduzione.html (1.9.2008).

Marinček, L., Čarni, A. 2002: Komentar k vegetacijski karti gozdnih združb Slovenije v merilu 1 : 400.000. Ljubljana.

Melik, A. 1957: Štajerska s Prekmurjem in Mežiško dolino. Ljubljana.

Mlinarič, J. 1991: Kartuziji Žiče in Jurklošter. Maribor.

Orožen, J. 1976: Jurklošter. Krajevni leksikon Slovenije III, Svet med Savinjskimi Alpami in Sotlo. Ljubljana.

Osnovne smernice za trajnostni razvoj evropskega turizma. 2003. Internet: www.park-goricko.org/download/ 9/2007/9/2740_4774_Zavarovana_obmocja_in_turizem.ppt (11.8.2008).

Pedološka karta Slovenije 1:25.000. Biotehniška fakulteta, Oddelek za agronomijo, Center za pedologijo in varstvo okolja. Ljubljana, 2002.

Placer, L. 1999: Strukturni pomen Posavskih gub. Geologija 41. Ljubljana.

Polajnar, J. 2006: Visoke vode v Sloveniji leta 2005. Ujma 20. Ljubljana.

Popisi prebivalstva 1869, 1880, 1890, 1900, 1910, 1931, 1948, 1953, 1961, 1971, 1981, 1991, 2002 in drugi podatki. Statistični urad Republike Slovenije. Ljubljana.

Ramovš, A. 1983: Gračniški slap. Slapovi v Sloveniji. Ljubljana.

Ramovš, A. 1997: Počerenski slap na Gračnici. Proteus 60-3. Ljubljana.

Slovenski E-forum, društvo za energetsko ekonomiko in ekologijo: Geotermalna energija. Internet: http:// www.ljudmila.org/sef/si/energetika/obnovljivi_viri/geotermalni.htm (5.7.2008).

Stopar, I. 1990: Jurklošter, umetnostni spomeniki. Enciklopedija Slovenije 4. Ljubljana.

Šifrer, M. 1997: Površje Slovenije. Geografski inštitut Antona Melika. Ljubljana.

Terensko delo maja 2007. 
Topole, M. 2007: Naravna in družbena geografija Krajevne skupnosti Jurklošter. Geografski inštitut Antona Melika ZRC SAZU. Ljubljana.

Uredba o spremembah in dopolnitvah Uredbe o posebnih varstvenih območjih Natura 2000. Uradni list RS 59/2007. Ljubljana.

Vegetacijska karta gozdnih združb Slovenije. Biološki inštitut Jovana Hadžija ZRC SAZU, 2002. Ljubljana. Wraber, M., 1960: Fitosociološka razčlenitev gozdne vegetacije v Sloveniji. Ljubljana.

Zorn, M., Komac, B. 2007: Probability modelling of landslide hazard. Acta geographica Slovenica 47-2. Ljubljana. doi: 10.3986/AGS47201 


\section{Turistični potencial demografsko ogroženega območja Jurklošter}

DOI: $10.3986 / A G S 49104$

UDK: 913:314.116(497.4Jurklošter)

COBISS: 1.01

IZVLEČEK: Članek obravnava demografsko ogroženo območje Krajevne skupnosti Jurklošter v jugovzhodnem delu predalpskega Posavskega hribovja, ki je del občine Laško. Opozarja na naravne in družbene razmere v pokrajini po drugi svetovni vojni, ki so privedle do neprekinjenega praznjenja območja. Predstavi značilnosti geografskega položaja, poselitve, naselij, prebivalstva in rabe tal ter gospodarskega razvoja. Poudarja pomen tukajšnje izjemne naravne in kulturne dediščine kot podlage za krepitev vloge turizma in rekreacije, ki bi poleg nekaterih komplementarnih dejavnosti lahko pomagala obrniti negativne prebivalstvene trende in zagotoviti nove vire prihodka. Ukvarja se predvsem z naravnimi in kulturnimi motivi kot pomembnimi sestavinami turističnega potenciala območja.

KLJUČNE BESEDE: geografija podeželja, demogeografija, demografsko ogroženo območje, naravna in kulturna dediščina, zavarovano območje, turistični potencial, Krajevna skupnost Jurklošter, slovenski predalpski svet

Uredništvo je prejelo prispevek 17. aprila 2008.

NASLOV:

dr. Maja Topole

Geografski inštitut Antona Melika

Znanstvenoraziskovalni center Slovenske akademije znanosti in umetnosti

Gosposka ulica 13, SI - 1000 Ljubljana, Slovenija

E-pošta: maja.topole@zrc-sazu.si

\section{Vsebina}

$1 \quad$ Uvod

2 Prebivalstveni in gospodarski razvoj regije v preteklosti

Socialno-ekonomske razmere danes

4 Turistični potencial kot podlaga novih razvojnih možnosti območja

4.1 Geomorfološki in hidrografski turistični motivi

4.2 Biogeografski turistični motivi

4.3 Zgodovinski, etno-socialni, ambientni, pejsažni in umetnostni turistični motivi 139

$\begin{array}{lll}4.4 & \text { Duhovna dediščina } & 139\end{array}$

5 Sklep 140

6 Literatura 141 


\section{Uvod}

Krajevna skupnost Jurklošter je $42 \mathrm{~km}^{2}$ veliko območje v jugovzhodnem delu predalpskega Posavskega hribovja, ki se razteza med Ljubljansko kotlino na zahodu in panonskim Sotelskim gričevjem na vzhodu. S svojim vzhodnim delom sega na Kozjansko. Na $21 \%$ površine občine Laško po podatkih popisa iz leta 2002 živi le slabih $6 \%$ njenega prebivalstva. Na jugu mejí na občino Sevnica, na vzhodu pa na občini Dobje in Šentjur. Pred prvo svetovno vojno je število njenih prebivalcev začelo počasi upadati, po drugi svetovni vojni pa je bilo praznjenje območja močno pospešeno. Zanimalo nas je, kje so vzroki za neugoden demografski razvoj in kakšne so možnosti za izboljšanje gospodarskega stanja pokrajine. Uporabili smo matematično-statistične metode in analizirali podatke iz popisa prebivalcev leta 2002. Tako smo dobili sliko o tukajšnji starostni in spolni strukturi prebivalstva, njegovi zaposlitveni strukturi, strukturi delovnih mest, značilnostih naravnega in selitvenega gibanja prebivalcev ter primerjavo s širšim prostorom. Ob poznavanju naravnogeografskih in kulturno-zgodovinskih prednosti območja (Topole 2007) smo želeli predstaviti tiste turistične motive, ki lahko pomenijo podlago uspešnemu turističnemu razvoju pokrajine.

\section{Prebivalstveni in gospodarski razvoj regije v preteklosti}

Tukajšnji gospodarski razvoj je temeljil predvsem na velikem gozdnem in vodnem bogastvu ter na omejenih zalogah nekaterih mineralnih in energetskih surovin (kremenčev pesek, rjavi premog). Konec 18. stoletja se je tu razvilo steklarstvo (Stara Glažuta, Jurklošter), po preselitvi steklarne v Hrastnik leta 1860 pa se je območje preusmerilo v papirništvo in lesno obrt oziroma kasneje lesno industrijo. Napredno gozdno gospodarjenje je vključevalo gojenje gozdnih dreves v drevesnicah in načrtno pogozdovanje. Cvetela je tudi trgovina, ki se je posebej razmahnila z izgradnjo železnice Dunaj-Trst, saj je ta po letu 1857 omogočila transport lesnih izdelkov do oddaljenih trgov v srednji Evropi, na Balkanu, v Aziji in severni Afriki (Jelovšek 1983). V 19. in v začetku 20. stoletja so ti kraji doživeli svoj največji razcvet. Medtem ko je bilo zaradi agrarne prenaseljenosti za večino takratnega slovenskega podeželja značilno izseljevanje in upadanje števila prebivalstva, je Krajevna skupnost Jurklošter leta 1900 dosegla maksimalno število prebivalcev. V njenih okvirih je tedaj živelo 1752 ljudi. Ljudje so imeli stalno delo v tovarni, v gozdu in v prevozništvu, v konicah pa je regija potrebovala tudi sezonske delavce. Tik pred prvo svetovno vojno je število prebivalcev začelo padati (leta 1910 jih je bilo 1707), potem pa je do druge svetovne vojne stagniralo (Popisi prebivalstva 1869 ...).

Slika 1: Število prebivalcev ob posameznih popisih po naseljih (Popisi prebivalstva 1869 ...).

Glej angleški del prispevka.

Okupacija in povojni družbeni procesi, nacionalizacija in razselitev proizvajalnih sredstev po drugih slovenskih krajih ter poslabšanje prometnih razmer zaradi uničujočih zemeljskih plazov in poplav so vodili v vse večje praznjenje območja. Gračnica je namreč hudourni potok in občasno poplavlja. Najhujše poplave so območje doletele leta 1954 (Kolbezen 1993) in pomenile konec obratovanja številnih tukajšnjih mlinov in žag. Odneslo je več mostov, sprožili pa so se tudi številni zemeljski plazovi. Ker cestne povezave niso obnovili vse do šestdesetih let 20. stoletja, je bilo območje proti zahodu popolnoma odrezano (Jelovšek 1983). Poplave, usadi in plazenje ob obilnih padavinah ogrožajo območje še danes (Dolinar in Vertačnik 2005; Polajnar 2006; Zorn in Komac 2007).

\section{Socialno-ekonomske razmere danes}

Povojno število prebivalcev (1646 ljudi leta 1948) se je do popisa leta 2002 več kot prepolovilo (778). V Krajevni skupnosti Jurklošter je leta 1991 živelo na $\mathrm{km}^{2}$ le 21 ljudi. Istočasno je bila gostota v Sloveniji 97, v Posavskem hribovju 69, v občini Laško pa 72 ljudi na $\mathrm{km}^{2}$. Leta 2002 je bila gostota poselitve tu le še 19 ljudi $/ \mathrm{km}^{2}$. V 100 letih se je torej število zmanjšalo za $55 \%$. Prebivalstvo ima tudi neugodno starostno strukturo. Po popisu leta 2002 je bil delež mladih, starih pod 15 let, 16,6\%, delež starih nad 64 let pa 18,25\%. Indeks starosti, razmerje med njunima številoma, pomnoženo s 100, ima ob normalni starostni sestavi vrednost med 40 in 50. V Sloveniji je imel v letu 2002 vrednost 96 (Josipovič in Repolusk 2007), v Krajevni skupnosti Jurklošter pa 110,1. V obdobju 1995-2002 smo za krajevno skupnost izračunali negativno stopnjo 
naravnega prirasta: $-8 \%$. Stopnja rodnosti je bila v tem obdobju $10 \%$, stopnja umrljivosti pa $18 \%$ o (v Sloveniji v istem obdobju 9,1 in 9,4). Posledično lahko v naslednjih desetletjih zato tu pričakujemo manjši naravni prirast. Če upoštevamo selitveno gibanje prebivalcev, se slika nekoliko izboljša. V obdobju 1995-2002 je selitveni prirast 29 ljudi; v krajevno skupnost se jih je dobro petino več priselilo kot odselilo.

V okviru delovnega kontingenta, to je prebivalcev, starih med 15 in 64 let, jih je delovno aktivnih le 280 ali 55,2 \% (v Sloveniji 59,5). V regiji ni pomembnejših obratov oziroma zaposlitvenih možnosti. $70 \%$ delovno aktivnih ljudi je delovnih migrantov. Polovica od teh migrira v drug kraj iste občine, tretjina v drugo občino iste statistične regije, $17 \%$ pa je zaposlenih v drugih statističnih regijah.

Nadpovprečno pomembna dejavnost je kmetijstvo z gozdarstvom, ki zaposluje kar $14 \%$ delovno aktivnega prebivalstva. $44 \%$ delovno aktivnih je zaposlenih v nekmetijskih, $40 \%$ pa v storitvenih dejavnostih, vendar se ti večinoma vozijo $\mathrm{v}$ zaposlitvena središča laške občine ali v sosednjo Sevnico. V naselju prebivališča je našlo delo $30 \%$ delovno aktivnih. Večina teh dela v primarnih dejavnostih, v kmetijstvu in gozdarstvu, v nekmetijskih in storitvenih dejavnostih pa ima regija le posamezna delovna mesta. Lokacijska divergenca, parameter, ki kaže razhajanje med številom delovno aktivnih po kraju bivanja in številom delovno aktivnih po kraju dela (število delovnih mest), ima v primeru ravnovesja vrednost 1 (Ravbar 2002). V Krajevni skupnosti Jurklošter pa je ta vrednost 3,11. Pomeni veliko prevlado števila zaposlenih nad številom delovnih mest. Delovna mesta v primarnih dejavnostih pripomorejo, da razhajanje ni še večje.

Edino središčno naselje je Jurklošter, a ta opravlja le središčne funkcije najnižje stopnje.

Osnovna problematika območja je torej naslednja:

- ogroženost regije zaradi naravnih nesreč (poplave, plazenje, usadi, erozija prsti);

- prevladujoča ekstenzivno kmetijstvo in gozdarstvo ter nepovezanost z drugimi gospodarskimi dejavnostmi;

- velika odvisnost prebivalcev od delovne migracije v zaposlitvene centre zunaj regije;

- podpovprečno število delovno aktivnih prebivalcev;

- pomanjkljivost in zastarelost prometne, energetske, komunalne in komunikacijske infrastrukture;

- šibkost osrednjega središčnega naselja;

- neovrednotenost spomenikov naravne in kulturne dediščine in

- neobstoj jasnih razvojnih načrtov in varstvenih con.

\section{Turistični potencial kot podlaga novih razvojnih možnosti območja}

Glede na nadpovprečno bogastvo naravnih in kulturnih znamenitosti lahko regija poišče novo razvojno perspektivo v razvoju turizma in rekreacije. Ob ustrezni promociji turistično povpraševanje po njej lahko relativno hitro oživi in sproži zanimanje turističnih posrednikov zanjo. Znotraj družbeno-ekonomskih sestavin sistema turizma, ki ga predstavlja Jeršič 1998, nas zato zanima predvsem turistična ponudba. Njene poglavitne sestavine so:

- turistični potencial (infrastruktura, naravne in družbeno-kulturne sestavine pokrajine);

- turistična opremljenost (objekti za bivanje, oskrbo, rekreacijo, zabavo, prevoz in informiranje);

- turistične organizacije in prebivalci receptivnih turističnih območij. Posebej se bomo posvetili predvsem turističnemu potencialu.

Obravnavana pokrajina leži nedaleč od pomembnih prometnic. Magistralna cesta in železnica Zidani most-Celje z železniško postajo Rimske Toplice (Globoko) v dolini Savinje ter magistralna cesta in železnica Zidani Most-Zagreb z železniško postajo Breg v dolini Save sta od Jurkloštra oddaljeni 14 oziroma $12 \mathrm{~km}$. Kot cilj izletnikov in rekreativcev pa je Jurklošter zanimiv tudi za bližnja zdraviliška kraja Rimske Toplice $(19 \mathrm{~km})$ in Laško $(22 \mathrm{~km})$ in urbana središča Sevnico $(20 \mathrm{~km})$, Celje $(33 \mathrm{~km})$ in Krško $(40 \mathrm{~km})$.

Nadpovprečne naravne in družbeno-kulturne sestavine so predpogoj za turistično-rekreativno privlačnost neke regije. Želimo jih identificirati, ovrednotiti, predstaviti in jih pripraviti za turistični obisk, to pomeni, poskrbeti za njihovo dostopnost, primerno opremljenost in varovanje. Na podlagi delitve spomenikov na naravno in kulturno dediščino ločimo naravne in kulturne turistične motive (Jovičić 1980).

V obravnavani regiji spadajo med najpomembnejše naravne turistične motive geomorfološki in hidrografski turistični motivi, biogeografski turistični motivi, med kulturne turistične motive pa prištevamo zgodovinske, etno-socialne, ambientne, pejsažne in umetnostne turistične motive ter duhovno dediščino. 


\subsection{Geomorfološki in hidrografski turistični motivi}

Skozi regijo je mogoče speljati geološko in geomorfološko učno pot. Zanjo je namreč značilna velika kamninska pestrost, s čimer je povezano bogastvo geomorfoloških oblik, pedoloških profilov, hidroloških pojavov, rastlinskih in živalskih vrst, pa tudi tipov rabe tal (Buser 1979; Šifrer 1997; Dozet et al. 1999; Dozet 2003).

Slika 2: Oblikovanost površja, višine, nakloni, hidrografske in pedološke razmere, raba tal in poselitev so močno odvisni od litološke podlage. Na območju Krajevne skupnosti Jurklošter med drugim najdemo: 1. karbonatne kamnine (apnenec in dolomit), ki prevladujejo, so najbolj odporne in povezane z največjimi nakloni, 2. kremenove konglomerate in peščenjake, 3. karbonske skrilavce, vidne v razkritem jedru antiklinale, 4. oligocensko morsko sivico na območju Polane, ki je močno podvržena eroziji, 5. in 6. slabo odporne terciarne (oligocenske in miocenske) peske, ki so na površju ohranjeni le v zaščitenih legah.

Glej angleški del prispevka.

Od litološke podlage je odvisen tip reliefa. Prevladuje rečno-denudacijski slemenasto-dolinasti, močno razčlenjeni relief, redkejša sta fluviokraški relief (vrh Lisce) in akumulacijski relief (posamezni odseki ob Gračnici, območje Mrzlega Polja). S prepustnostjo kamnin je povezan način vodnega odtoka (menjata se površinski odtok, ki prevladuje, in redkeje podzemni odtok, drugje, zlasti v širšem dnu dolin, pa je zaradi oteženega odtoka svet zamočvirjen). Zaradi selektivne erozije marsikje izstopajo odpornejše kamnine, na primer litotamnijski apnenec sredi miocenskih peskov v območju Marijine vasi ali igle in pomoli iz odpornega triadnega apnenca soteski Grohotje. Z reliefom so povezane mikroklimatske razmere, pa tudi način razporeditve gozda in izkrčenega sveta.

Slika 3: Pogled z Vrha nad Laškim (565 m) proti jugu na razčlenjeno gozdnato območje Krajevne skupnosti Jurklošter. Gozd zavzema skoraj tri četrtine vseh njenih površin. V ozadju je Lisca $(948 \mathrm{~m})$.

Glej angleški del prispevka.

Slika 4: Pogled z Lisce proti severu. Očitna je razlika med višjim, bolj strmim svetom na odpornih mezozojskih karbonatnih kamninah in nižjim površjem blažjih oblik na manj odpornih terciarnih kamninah. Prvega pokriva strnjen gozd (Lapor, Sekovca, Tajna), drugi pa je izkrčen in poseljen (spredaj Paneče in Polana, v ozadju Vrh nad Laškim).

Glej angleški del prispevka.

Pogled od severa proti jugu daje vtis povsem gozdnate pokrajine, pogled v obratni smeri pa odkriva številne krčevine z malimi naselji in zaselki. V obravnavani pokrajini se menjajo kamnine različne starosti (od permokarbonskih, do najmlajših aluvialnih), različne trdote in odpornosti (od mehkih, kakršna je izredno erodibilna oligocenska morska sivica oziroma lapornata morska glina v okolici Polane, do prevladujočih trdih apnencev in dolomitov, ki jim vložki roženca še povečujejo odpornost), od sipkih (oligocenski in miocenski peski, recentni grušč) do kompaktnih, od vodoprepustnih karbonatnih, do neprepustnih silikatnih, od sedimentnih, do redkih vulkanskih, ki so posledica tukajšnjega terciarnega vulkanizma (Blatni Vrh). V pokrajini se menjajo kopasti in priostreni vrhovi, zaobljena slemena in ostri grebeni, pomoli, soteske, ozke globoke doline V-oblike in širši dolinski odseki s poplavnimi ravnicami ali celo zamočvirjenim dnom, strmi jarki in grape in plitvi zaobljeni dolci, strma in prepadna pobočja in uravnan zakrasel svet, valovita položna pobočja in skalne rebri, igle in spodmoli (Topole 2007). Med zanimive površinske oblike lahko prištejemo tudi dva spomenika oblikovane narave - v skalo vklesana konja v soteski Gračnice nedaleč od Rimskih Toplic, ki sta v srednjem veku služila kot kažipota (Gržan 2006).

Posebej privlačni so vzpeti deli površja - v osrednjem, gozdnatem delu (Fesinge, $643 \mathrm{~m}$, Artvišče, $644 \mathrm{~m}$, Tajna - Sv. Trojica, $851 \mathrm{~m}$, Voluš, $778 \mathrm{~m}$ ), v južnem, najvišjem delu pa greben s številnimi razglednimi vrhovi (Radež, 765 m, Vršica, 771 m, Lisca, 948 m, Mala Lisca, 934 m, Ješovec, 934 m, Ivc, 875 m, Ojstrež, 917 m, Rudenik, 900 m). Greben je del narivnega čela, ki mu sledimo od Podkuma, mimo Radeč, po južni strani Lisce, vse do Bohorja na vzhodu (Buser 1979). Ker so bile kamninske plasti narinjene proti jugu, so severna pobočja nagnjena med 20 in $30^{\circ}$, južna pobočja nad Savo pa pogosto presegajo naklon $30^{\circ}$ in imajo marsikje obliko stometrskih ali celo višjih prepadov. Z reliefnega, klimatskega (Gams 1972) in rastlinskega vidika (Wraber 1960) greben pomeni prehodno območje, kjer se stikajo elementi predalpskega in dinarskega sveta. Izrazita reliefna meja, na katero se navezuje tok reke Save, se je v preteklosti odrazila tudi kot deželna meja. Tu se je namreč oblikovala meja med Štajersko in Kranjsko.

Slika 5: Gračnica, potok z značilnostmi gorskega hudournika, lahko v času močnejših nalivov, predvsem poleti, močno naraste. Glej angleški del prispevka. 
Krajevna skupnost Jurklošter ima zaradi pogostih neprepustnih vložkov roženca in zaradi velikih naklonov kljub prevladi karbonatnih kamnin gosto rečno mrežo. Večinoma pripada porečju Gračnice $\left(96,6 \mathrm{~km}^{2}\right.$; Kolbezen 1998) izjema je le jugozahodno pobočje Lisce, ki se po Podvinskem, Liškem in Črnem potoku odmaka direktno v Savo. Gračnica je $25 \mathrm{~km}$ dolg vodotok, ki izvira na višini $550 \mathrm{~m}$ severno od Planine pri Sevnici, teče proti zahodu in se jugovzhodno od Rimskih Toplic izliva v Savinjo. Od izvira do izliva premaga višinsko razliko $350 \mathrm{~m}$. Ima značaj gorskega oziroma hudournega vodotoka $\mathrm{z}$ alpskim dežno-snežnim vodnim režimom, za katerega je značilen primarni višek aprila, sekundarni pa novembra ali decembra (Hrvatin 1998). Zaradi litoloških in reliefnih razlik ima rečica različno erozijsko sposobnost. Zapleteno pot ima že pred Mrzlim Poljem. Miren tok po lapornati podlagi, ki je delno reguliran (Govedič in ostali 2006), prekinejo pregrade iz apnenčevo-kremenčevega konglomerata. Rečica jih premaguje na različne načine: z obtokom, vrezovanjem soteske in v slapiščih. Posebej slikovit je Počerenski slap (Ramovš 1997).

Slika 6: Gračniški slap pri Marofu v Mrzlem Polju. Voda priteče z mehke miocenske lapornate podlage in pada v dveh, 8 in $4 \mathrm{~m}$ visokih slapovih prek tektonsko dvignjene dolomitne pregrade. Pot proti Jurkloštru nadaljuje skozi ozko sotesko.

Glej angleški del prispevka.

V mehki miocenski lapornati podlagi, ki sledi, je več ribnikov, ki so nastali z zajezitvijo Gračnice pri Marofu. Imajo pomembno vlogo v ribogojništvu, ribištvu in rekreaciji.

Gračniški slap pri Marofu (Mrzlo Polje) označuje mejo med terciarno in triasno kamninsko podlago oziroma med mehkimi miocenskimi plastmi na vzhodu in trdim dolomitom na zahodu. Tu se značaj doline popolnoma spremeni, spremeni se tudi raba tal: vzhodno od tu prevladuje izkrčen in poseljen svet blagih oblik, zahodno od tu pa višji razčlenjen svet s prevlado gozda. Med dvema prečnima prelomoma je tektonsko dvignjena dolomitna pregrada, v katero se Gračnica ni mogla sproti vrezovati, zato je za njo nastalo jezerce. Del vode so domačini namenili pogonu žage, del pa pada čez steno v dveh slapovih, visokih 8 in $4 \mathrm{~m}$. Pod stenama nastajata tolmuna. Območje je tektonsko precej razlomljeno in razkosano v kamnite bloke (Ramovš 1983).

Slika 7: Soteska Grohotje pri Lipnem Dolu. V do 500 m globoki, v trde karbonatne kamnine vrezani dolini Gračnice se vrstijo razširitve z ozkimi poplavnimi ravnicami in zožitve z mogočnimi skalnimi pomoli in iglami.

Glej angleški del prispevka.

Posebno slikovit je tok Gračnice med Mišjim Dolom in izlivom v Savinjo. Tu gre za primer inverznega reliefa, saj je rečica vrezana do 500 m globoko v severno krilo Litijske antiklinale. Soteska Grohotje se je namreč oblikovala sočasno z gubanjem in tu je nastal tudi velik ujeti okljuk. Zaradi litoloških razlik in tektonske pogojenosti se menjajo kanjonski in razširjeni dolinski odseki, vrstijo se igle, možici, skalni pragovi in izjemno strmi jarki. Dolinsko dno je poseljeno le v razširjenem delu (Lipni Dol). Drugje so na dnu le posamezni vodni obrati, domovi pa so raztreseni višje po sončnem pobočju nad desnim bregom Gračnice.

Pokrajina je del Dinaridov oziroma Notranjih Dinaridov in je zanimiva tudi z vidika tektonike. Paleozojske, mezozojske in terciarne kamninske plasti so bile zaradi pritiskov s severa v terciarju in kvartarju nagubane, naknadno pa je bilo območje še tektonsko razlomljeno (Placer 1999). Na tektonskih prelomih in njihovih stičiščih prihajajo nedaleč od Jurkloštra na dan izviri termalne vode $\left(21-43^{\circ} \mathrm{C}\right)$, (Rimske Toplice, Laško). Območje namreč pripada Planinsko-Laško-Zagorski geotermični regiji (Slovenski E-forum ... 2008).

\subsection{Biogeografski turistični motivi}

Krajevna skupnost Jurklošter je sicer izrazito gozdna pokrajina, kjer so v popolni prevladi različne združbe bukovega gozda (Marinček in Čarni 2002). Zaradi velikega deleža odpornih karbonatnih kamnin, strmega in toplotnemu obratu izpostavljenega sveta gozd pokriva kar 73 \% vseh površin. Regija spada v predalpsko fitogeografsko območje, vendar moramo poudariti njen prehodni značaj. Nedaleč proti jugovzhodu je namreč stična točka predalpskega, subpanonskega in preddinarskega fitogeografskega območja, s čimer je povezana izjemna rastlinska pestrost. Na karbonatni podlagi na posameznih vrhovih in osojnih strminah najdemo celo nekatere glacialne relikte, na prisojnih rastiščih pa uspevajo termofilne rastlinske vrste (Wraber 1960). 
Gozd nudi zatočišče številnim živalskim vrstam, predvsem srnam, jelenom in divjim prašičem, dragocen habitat pa pomenijo tudi tukajšnji vodotoki, kjer domujejo različne sicer ogrožene ribje vrste (Govedič, Kotarac in Grobelnik 2006).

\subsection{Zgodovinski, etno-socialni, ambientni, pejsažni in umetnostni turistični motivi}

Tu gre za staro kulturno pokrajino s pomembnimi kulturno-zgodovinskimi spomeniki.

Arheološke najdbe dokazujejo poseljenost območja Jurkloštra že v paleolitiku. Pomembne prometnice vzdolž Savinje, Save in prek prevala Sele, $675 \mathrm{~m}$, pod Lisco, so ljudi privabljale v vseh obdobjih, vendar je bila gostota poselitve tu še v rimski dobi nizka. Za rimski čas je namreč značilna danja lega naselij, lega $\mathrm{v}$ neposredni bližini prometnic in rodovitnega polja, takega prostora pa je v obravnavanem območju primanjkovalo. $\mathrm{V}$ poznoantični dobi, $\mathrm{v}$ času od 2. polovice četrtega do konca 6. stoletja, se je ob vojnah in vpadih barbarov z vzhoda krepila vloga težje dostopnih krajev, saj so nudili večjo varnost. Prebivalci so se zatekali v odmaknjene, višje in težko dostopne dele hribovitega sveta. Tu so si utrdbe gradile tudi vojaške posadke. Na območju Krajevne skupnosti Jurklošter so iz poznoantičnega obdobja znani ostanki utrjenih naselij Gradec pri Prapretnem in Vranja peč pri Lipnem Dolu. Prvo spada celo med najpomembnejše poznoantične spomenike vzhodnoalpskega območja (Ciglenečki 1992; Ciglenečki 2007).

Na poselitev, gospodarski in kulturni razvoj območja so kasneje odločilno vplivali menihi. V 12. stoletju so se tu naselili kartuzijani, v 16. stoletju pa so jih nasledili jezuiti. Samostan je bil razpuščen z jožefinskimi reformami leta 1773 (Orožen 1976).

Slika 8: Večino tukajšnjih naselij sestavljajo majhni zaselki in samotne kmetije, ki sežejo visoko nad dna dolin. Na sliki je osojna stran Lisce z zaselkom Staro Glažuto (500 m) v Lahovem Grabnu.

Glej angleški del prispevka.

Na stiku alpskega (predalpskega), subpanonskega in dinarskega sveta se menjajo območja nižjega terciarnega sveta, kjer je gozd večinoma izkrčen, in razgibana gozdna območja na trdi karbonatni kamninski podlagi. Gozd pokriva skoraj tri četrtine vseh površin in ima v prvi vrsti varovalni pomen. Vezan je na zelo strm svet in odporne karbonatne kamnine ter je v povprečju nagnjen kar $26^{\circ}$. Nasprotno je povprečna nagnjenost izkrčenega sveta le $14^{\circ}$; ta je najpogosteje izkoriščen za travnike in pašnike (Karta dejanske rabe tal 1996 in 2001). Ćeprav poseljene površine zavzemajo med vsemi površinami le 2,6-odstotni delež (Topole, 2007), stavbna dediščina močno pripomore k pokrajinski privlačnosti. Tukajšnje hiše uvrščamo v osrednjeslovenski tip, ki je po obliki bližje alpski kot panonski hiši (Drozg 1998). Za dna dolin je značilna obcestna poselitev (ob vodotokih se posamezno pojavljajo le vodni obrati - žage, mlini, mala elektrarna), za pobočja, slemena, vrhove in prevale pa razpršena poselitev in poselitev v obliki samotnih kmetij. Posebej je treba omeniti posamezne zgodovinske, umetnostne in tehnične objekte kot so: takoimenovana Vila Haus, stara upravna zgradba steklarne, kasneje v graščinski lasti, kartuzijanski kompleks v Jurkloštru z ostanki samostana in obzidja, s poznoromansko oziroma zgodnjegotsko cerkvijo sv. Mavricija in z grajskim poslopjem s konca 18. stoletja ter rečni mostovi na Gračnici.

\subsection{Duhovna dediščina}

Bogata duhovna dediščina je povezana predvsem z nekdanjim slovitim verskim in kulturnim središčem, s kartuzijo v Jurkloštru. Ustanovljena je bila okrog leta 1170 in velja za eno najstarejših srednjeevropskih kartuzij. Tu so v miru in odmaknjenosti delovale nekatere evropsko pomembne zgodovinske osebnosti, med njimi srednjeveški pisci: Odon iz Novare (prior 1189-1190), pesnik Sifrid Švabski (sredi 13. stoletja), Mihael iz Prage (prior 1391-1401) in avtor spisov z versko, jezikovno, filozofsko in pedagoško vsebino, tudi pisec prve tiskane knjige na Slovenskem Nikolaj Kempf (prior 1449-1451 in 1467-1490) (Mlinarič 1991; Gržan 2006).

Slika 9: Kartuzija je imela v zgodovini Jurkloštra vsestransko pomembno vlogo. Tu so v srednjem veku delovali evropsko pomembni pisci. $\checkmark$ zadnjem času ponovno postaja versko, duhovno in kulturno središče, pridobiva pa tudi turistični pomen.

Glej angleški del prispevka. 
V sklopu samostana je tudi zeliščni vrt, ki vsebuje elemente srednjeveških samostanskih vrtov in je bil nekoč menihom pomemben vir zelišč v zdravilstvu.

Raziskovalci povezujejo s samostanom tudi tragično zgodbo iz 15. stoletja o Frideriku II. Celjskem in njegovi drugi ženi Veroniki Deseniški. Domnevajo, da je bila pokopana v kapiteljski dvorani tega samostana, vendar naj bi njen grob leta 1471 med svojim vpadom oskrunili Turki (Gržan 2006).

Ker je Gračnica vključena v mrežo posebej varovanih območij Natura 2000, z namenom vzdrževati ali obnoviti ugodno stanje ohranjenosti naravnih habitatov in prostoživečih živalskih in rastlinskih vrst (Uredba ... 2007), se bomo med različnimi možnostmi turističnega razvoja opredelili za trajnostni oziroma ekoturizem (okoljski turizem) in kulturni turizem.

Naravne razmere sicer omogočajo najrazličnejše oblike rekreacije (kolesarjenje, tek, pohodništvo in sprehodi, rolanje, lov, ribolov, veslanje, plavanje, vožnja s kajakom oziroma kanujem, športno plezanje, lokostrelstvo, jahanje, tek na smučeh in alpsko smučanje), vendar moramo biti pri planiranju teh dejavnosti zelo previdni. Enega predlogov mogočih ukrepov za trajnostno oblikovanje turistične politike najdemo v Normah za izvajanje prostorske zasnove turizma (Jeršič 1998).

Negativnim vplivom rekreacije se lahko izognemo s coniranjem varovanih območij oziroma z omejitvijo strogo varovanih območij, območij z dovoljenim razvojem okolju prijaznih oblik turizma in območij, kjer je možen razvoj turistične infrastrukture (Osnovne smernice ... 2003). Blažimo jih z usmerjanjem obiskovalcev na potí, s skrbjo za večjo tehnično kakovost poti in z dobro informacijsko opremljenostjo spomenikov (Golob in Polanšek 2009). Učinek rekreacije je odvisen tudi od statusa, ki ga ima rekreacijsko območje. Legalizacija določenih rekreacijskih območij omogoča boljši nadzor kot je mogoč v primeru prevlade površin, ki so rekreaciji namenjene le deloma ali občasno.

\section{Sklep}

Območje Krajevne skupnosti Jurklošter je zahodni del Kozjanskega, del spodnjega Posavja in jugovzhodni del težko prehodnega predalpskega Posavskega hribovja. Ima velik naravni in kulturni potencial, ki ga je krajevna skupnost nekoč že polno izkoriščala. Ob prehodu iz 19. v 20. stoletje je dosegla maksimalno število prebivalcev, imela visoko razvito gospodarstvo, tudi nekmetijsko, in celo potrebe po dodatni delovni sili. Imela je pozitivno selitveno bilanco: v regijo so se priseljevali delavci od drugod. Po drugi svetovni vojni so nastopile za regijo izrazito neugodne družbenopolitične in gospodarske razmere. Obstoječa proizvajalna sredstva so bila regiji odtujena in preseljena v druge slovenske kraje. Okoliščine pa so se drastično poslabšale s katastrofalno ujmo junija leta 1954, ko je bilo ob povodnji uničenih več mostov in vodnih obratov, sprožili so se tudi številni zemeljski plazovi. Cesta ob Gračnici, ki je povezovala Jurklošter z $12 \mathrm{~km}$ oddaljeno magistralno cesto ob Savinji, ni bila sanirana vse do šestdesetih let. Prebivalcem, ki so pred tem že izgubili večino delovnih mest, je bilo onemogočeno migriranje proti glavnim zaposlitvenim in oskrbnim centrom - Rimskim Toplicam, Laškemu in Celju. Že v prvem desetletju je regija izgubila kar 17 \% prebivalcev, ob zadnjem popisu leta 2002 pa jih je imela le pol toliko kot pred 100 leti.

Glede na prevladujočo gozdno rabo tal v regiji (73\%) bo kmetijstvo z gozdarstvom s $14 \%$ od vseh delovno aktivnih prebivalcev še ohranjalo relativno pomembno vlogo. A potrebna je njegova intenzifikacija, racionalizacija in modernizacija.

Veliko odvisnost prebivalcev od delovne migracije v zaposlitvene centre, oddaljene od Jurkloštra do $30 \mathrm{~km}$, bi ob ustreznih ukrepih lahko omilili z načrtnim razvojem turizma in rekreacije in z njima povezanih dejavnosti. Tak razvoj že omogoča bogastvo raznovrstnih turističnih motivov, ki smo jih predstavili in utemeljili (geomorfološki, hidrografski, biogeografski, zgodovinski, etno-socialni, duhovni, ambientni, pejsažni in umetnostni turistični motivi), bistveni posegi pa bi bili potrebni na področju turistične opremljenosti, organiziranosti in usposobljenosti prebivalstva. Tu predvidevamo naslednje možne ukrepe:

- izgradnja modernega ogrevalnega središča na lesno biomaso (dobra praksa je znana že v Sloveniji, npr. KIV Vransko d. d. 2008). Učinek je lahko večstranski - socialno-ekonomski, ekološki in politični: pridobivanje lesnih sekancev, izkoriščanje obnovljivih virov energije, čiščenje gozdov oziroma izkoristek obilja lesa, poškodovanega v naravnih ujmah, zmanjšanje stroškov za ogrevanje objektov in segrevanje vode, zmanjšanje emisij, manjša odvisnost od tujih virov energije in možnost odpiranja novih delovnih mest; 
- uvedba kmečkih trgovin in s tem uspešnejše trženje kmetijskih pridelkov in izdelkov domače predelave, zlasti v primeru ekološkega kmetovanja in razvoja turizma;

- uvedba turizmu in rekreaciji komplementarnih obrtnih dejavnosti (npr. oživitev nekoč pomembne lesne obrti in nadaljevanje tradicije zeliščarstva);

- razvoj osebnih storitvenih dejavnosti;

- osnovanje literarnega parka oziroma razvoj kulturnega turizma po vzoru nekaterih tujih primerov (Literarni parki ..., 2008). Spodbudno okolje, zgodovina območja in z njim povezane zgodbe bi lahko vplivale na inspiracijo umetnikov besede;

- obnova osrednje ceste skozi dolino Gračnice (na eni strani zagotovitev lažje prevoznosti z motornimi vozili, na drugi pa omejitev prometa motornih vozil z uvedbo vstopne pristojbine);

- ureditev kolesarskih poti;

- ureditev osrednje pešpoti;

- ureditev prometno-informacijskih točk ob vstopih v dolino Gračnice in ob železniških postajah Rimske Toplice (Globoko) in Breg (oskrba s promocijskim gradivom o naravnih in kulturnih znamenitostih, o gostinskih in turističnih objektih, s podatki o zmogljivostih in odpiralnih časih, oskrba z itinerariji, predlogi tematskih poti, organizacija prevoza obiskovalcev, ki so do izhodiščnih točk pripotovali s sredstvi javnega prometa, to je, $\mathrm{z}$ avtobusom in vlakom (taksi služba, izvoščki, najem koles, turistični avtobus oziroma kombi), organizacija izletov);

- skrb za trajnostno mobilnost in uvedba spodbudnih paketov za uporabnike železnice;

- coniranje varovanih območij (tri cone različne strogosti varstvenega režima);

- ureditev osrednje kulturno-informacijske točke v Jurkloštru (muzej, projekcijska dvorana, izobraževalno središče, kulturno središče);

- vzpostavitev spletne strani Krajevne skupnosti Jurklošter;

- vzpostavitev elektronske mreže storitev (vnaprejšnji dogovori o prevozih, obiskih kulturnih znamenitosti, organizaciji izletov in vodenju po tematskih poteh ter o kulturnih prireditvah);

- priprava itinerarijev oziroma tematskih (učnih) poti in tematskih zemljevidov;

- oprema različnih tras z informacijskimi tablami, kažipoti, počivališči (parkirišči), razgledišči in piknik prostori;

- ureditev odlagališč odpadkov;

- ureditev vodovoda, kanalizacije in čistilne naprave;

- povezava in sodelovanje javnega in privatnega sektorja (npr. zdravilišč v Laškem in Rimskih Toplicah in turističnih ponudnikov v Krajevni skupnosti Jurklošter);

- izobraževanje in usposabljanje prebivalcev za opravljanje storitev, povezanih s turizmom;

- ureditev oziroma izgradnja gostinskih in prenočitvenih zmogljivosti ter manjših športnih objektov.

Utemeljili smo torej, v čem je krajevna svojskost in kaj pomeni identiteto območja. Sledili naj bi aktivno varovanje ugotovljenih prednosti, njihova krepitev in promocija. V regijo lahko privabimo nove obiskovalce ter poskrbimo za njihovo izobraževanje in kulturno udejstvovanje. Oblikujemo lahko celó blagovno znamko. Vendar moramo turizem in rekreacijo $\mathrm{v}$ regiji načrtovati v skladu $\mathrm{z}$ načeli trajnostnega razvoja, kar pomeni, da je treba upoštevati kvalitativno in kvantitativno zmogljivost agrarne pokrajine - ne le s tehničnega in ekonomskega, ampak tudi z ekološkega in psihološkega vidika. Le tako bo majhno ruralno območje postalo prepoznavno in bo ohranilo svojo turistično privlačnost in konkurenčnost.

\section{Literatura}

Glej angleški del prispevka. 